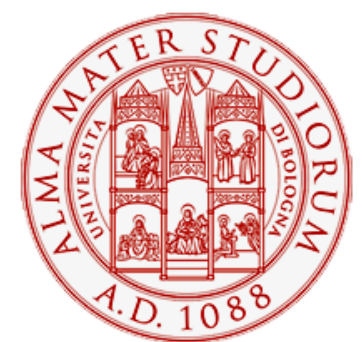

Alma Mater Studiorum - Università di Bologna DEPARTMENT OF ECONOMICS

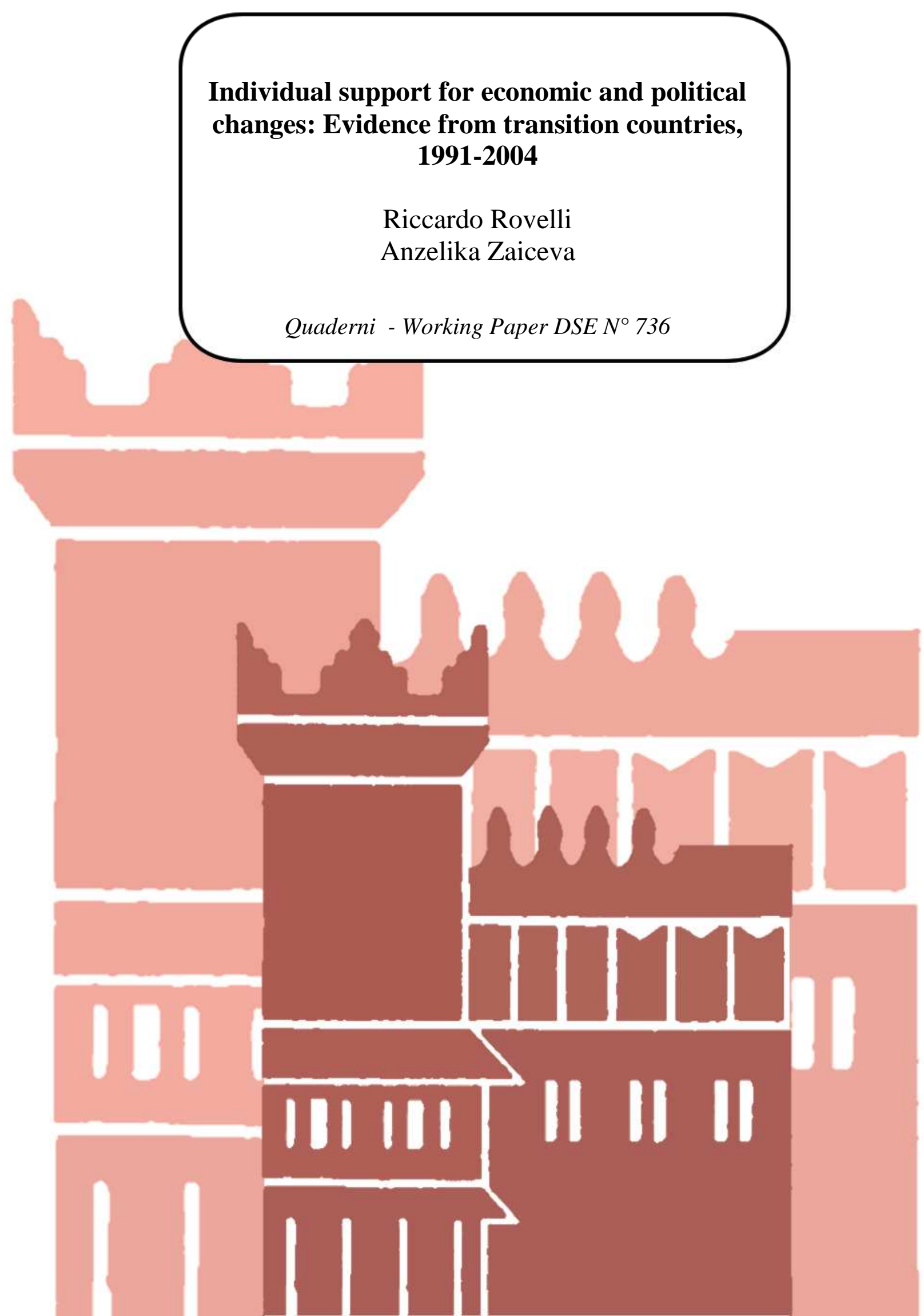




\title{
Individual support for economic and political changes: \\ Evidence from transition countries, 1991-2004
}

\author{
Riccardo Rovelli * Anzelika Zaiceva **, 1
}

January 2011

\begin{abstract}
Using a unique dataset for 14 transition economies, we propose a new measure for individual evaluations of transitional reforms, which we use to study, for the first time, the evolution of support for economic and political reforms from 1991 to 2004. We show that support for economic changes has been increasing over time after an initial drop, while support for political reforms has generally been higher. Support attitudes are lower among the old, less skilled, unemployed, poor, and those living in the CIS countries, especially during the 1990s. We also find evidence that transition-related hardship, opinions on the speed of reforms, political preferences and preferences towards redistribution, ideology and social capital matter. Finally, we show that individual preferences for state ownership and the quality of political institutions contribute mostly to explaining the lower levels of support in the CIS countries.
\end{abstract}

Keywords: Political Economy; Public Support; Reforms; Transition.

JEL Classification: O57, A13, P26, P36.

* University of Bologna and IZA. E-mail: riccardo.rovelli@ unibo.it

** University of Bologna and IZA. E-mail: anzelika.zaiceva@ unibo.it

\footnotetext{
${ }^{1}$ Both authors acknowledge use of data from the New Europe Barometer surveys. We are grateful to IZA for making several surveys available to us and to Fondazione Cassa dei Risparmi di Forli and the Volkswagen-Stiftung for financial support. We thank Tito Boeri, Irina Denisova, John Earle, Mihails Hazans, Andrea Ichino, Hartmut Lehmann, Chiara Monfardini, Richard Rose, Claudia Senik, Zahra Siddique, Jonathan Wadsworth and seminar participants at the University of Bologna, Bocconi University, Moscow Higher School of Economics, BICEPS Stockholm School of Economics in Riga, IZA and CIDE, as well as participants at the Fourth IZA-World Bank Conference on Employment and Development for helpful comments and suggestions. A preliminary version of this research has appeared as "Transition fatigue? Cross-country evidence from micro data", IZA Discussion Paper No. 4224, June 2009.
} 


\section{Introduction}

In the last two decades former socialist countries went through the unprecedented experience of a parallel transition to a market economy and to democracy. Although the paths of reform implementation and the sequence of the reforms differed across countries, transitional reforms soon produced both economic "winners" and "losers" (Brainerd, 1998; Terrell, 1999), and for those who were less ready or able to face these changes, the costs of transition may well have outweighed, at least for some time, its benefits.

Somewhat in parallel with the overall economic trends, life satisfaction in these countries collapsed in the beginning of 1990s and recovered subsequently (Easterlin, 2009), although it remained substantially lower than in Western economies (Guriev and Zhuravskaya, 2009). Consistent with this and in a stark contrast with the pre-crisis strong economic performance, there was also a widespread dissatisfaction with the outcomes of transition. In 2007, 49 percent of respondents disagreed (and only 35 percent agreed) with the statement that the economic situation in their country was better than around 1989, with similar numbers corresponding to the political situation (EBRD, 2007a; Guriev and Zhuravskaya, 2009). Also privatization, one of the most important transition reforms, received low support, with over 80 percent of respondents willing to revise it (EBRD, 2007a; Denisova et al., 2009).

To shed light upon the extent and evolution of public support for reforms, we employ a unique dataset, so far largely unexploited by economists, and construct new measures of support for the economic and political systems. These data allow us to document, for the first time, how support for the economic and political systems has been evolving in 14 countries over the entire transition period (1991-2004). We then analyze what factors have been driving these attitudes, how their impact changed throughout the period and why support was lower in some countries than in others.

As new economic policies and reforms are scrutinized through the channels of representative democracy and of civil society, the support of the general public becomes a crucial factor for their successful implementation. A large theoretical political economy literature has shown that voters' opinions are crucial for the successful implementation of reforms, and that interest group coalitions may influence or even reverse the reform process (see Roland, 2002, for a comprehensive discussion). Both ex-ante and ex-post political constraints are important, as feasibility constraints may prevent reforms from being accepted, while policy reversals can occur after reforms have been already implemented (ibid). Reforms are often adopted as part of a trial-and-error procedure under aggregate (as well as individual) uncertainty, and in the absence of credible compensating mechanisms for losers. Thus reforms may be resisted ex-ante even when they would be ex-post beneficial (Fernandez and Rodrik, 1991) or, when enacted, they may face ex-post political opposition 
from those who have experienced economic losses. Moreover, reforms are endogenous to the economic outcomes of previous reforms, and in particular to their distributional impact (Kim and Pirttilä, 2006). However, as the suddenness and spread of the transformation in transition economies were to a large extent unexpected and certainly unprecedented, it provides the context for a (quasi) natural experiment of reform adoption (Landier et al., 2008; Alesina and Fuchs-Schueldeln, 2007). This fact allows us to treat the initial reforms as a largely exogenous event, on the basis of which individuals then formulate their subjective assessments. This feature is unique to transition economies and would not hold in many development countries.

Several empirical studies are relevant for the purpose of our work, including those that employ macro-economic variables to explain voting behavior (Fidrmuc, 2000), support for the market economy (Hayo, 2004; Kim and Pirttilä, 2006) or "capitalism aversion" (Landier et al., 2008), as well as the recent cross-country studies that use micro data to analyze the "unhappiness in transition" (Guriev and Zhuravskaya, 2009; Easterlin, 2009) or the determinants of support for a revision of privatization policy (Denisova et al., 2009). ${ }^{2}$ Most of the existing studies, however, either use aggregate level data or are limited to only one country or one year. ${ }^{3}$ Moreover, voting preferences are likely to be imperfect measures of attitudes towards reforms. Since institutions are different across countries, such indirect measures may reflect both attitudes and institutions (Scheve and Slaughter, 2001; Mayda, 2006). On the other hand, measures based on attitudes towards the "market economy" or "democracy" are also likely to be biased since, especially in the beginning of transition, respondents may not know the precise implications of these terms. In addition, many studies do not explore the motives for the widely diverging level of support for the new policies across different countries. Finally, due to the subjective nature of the information gathered from the survey data, individual-specific (as well as cross-country) differences in the interpretation of these questions and in the perceptions of scales are important and need to be taken into account (Bertrand and Mullainathan, 2001).

In this paper we attempt to overcome these problems by employing a unique data set of comparable surveys in 14 transition economies over 1991-2004, thus covering the entire period from the beginning of transition up to the first Eastern EU enlargement. We differentiate between the earlier period of recession (1991-1998) and the later period of economic growth (2000-2004). We propose a new measure of public support and distinguish attitudes towards the economic and the political systems. In addition to standard individual characteristics, we are able to analyze factors that are usually unobservable to researchers, such as individual preferences and values, social capital or

\footnotetext{
${ }^{2}$ See Rovelli and Zaiceva (2008) for a comprehensive review of related literature.

${ }^{3}$ Easterlin (2009) and Guriev and Zhuravskaya (2009) constitute an exception, but they analyze a different question.
} 
ideology, as well as individual experiences with transition, perceptions of corruption and opinions on the speed of reforms. We also attempt to find some explanations for the lower support towards the reform process in several countries. Finally, we seek to reduce potential biases by constructing our dependent variable as a difference across evaluations for the same individual, thus differencing away individual and evaluation-specific factors, such as pessimism. To the best of our knowledge, our paper is the first one that analyses these questions using individual level data in a cross-country framework for this time span. ${ }^{4}$

The remainder of the paper is structured as follows. Section 2 provides a brief overview of the transition-specific background. Section 3 presents the data, discusses measurement issues and outlines the empirical model. The socio-economic determinants of individual attitudes towards changes in the economic and political systems are examined in Section 4. Section 5 suggests some potential explanations for the more critical attitudes towards transition in the CIS countries. Section 6 presents sensitivity checks and Section 7 concludes.

\section{Transitional reforms in Central and Eastern Europe}

The implementation of political and economic reforms began in the early 1990s in most countries in Central and Eastern Europe (CEE) and in the Commonwealth of Independent States (CIS). However, the paths of reform implementation and the sequence of the reforms differed across countries - a difference which is sometimes exemplified in the distinction between a so-called "bigbang" approach and "gradualism". 5 The transition process has been characterized almost everywhere by an initial deep recession, which in many countries also involved widespread unemployment. However, the pattern, depth and duration of this transitional recession and the speed of the subsequent recovery differed considerably across countries, with CEE countries, on average, recovering faster. A common feature to all the transition economies was the need to refocus the orientation of international trade, to restructure internal production, and to reallocate labor across regions, sectors and firms (Campos and Coricelli, 2002). Privatization, trade liberalization, macroeconomic stabilization and economic restructuring took place in a situation of institutional change, where many institutions that had hitherto provided social protection collapsed and others,

\footnotetext{
${ }^{4}$ The sources of popular support for political regimes in general and democracy in particular have been analyzed widely by political scientists using, among others, data from the New Democracy Barometers (see, for example, Rose, 2007, Lazar, Mishler and Rose, 2007, Mishler and Rose, 2008, 2002, 2000a and 2000b). We also refer to these studies for the presentation of sampling framework, methodology and representativeness of this dataset.

${ }^{5}$ Although a simplification and generalization, these definitions are useful for a general description of the transition process. See, for example, Roland (2002) for a comprehensive discussion of the political economy of transition and a survey of studies on economic policy reform. Note that countries differed also in the initial conditions, a fact that must be taken into account when modeling the outcomes of transition.
} 
such as taxation or banking, had to be introduced practically ex novo. The initial stages of transition brought about remarkable increases in income inequality in all countries, including those that had managed to avoid large increases in unemployment rates (Milanovic and Ersado, 2008).

One of the most important criteria for assessing the success of transition is a country's achievement in reallocating labor (Boeri and Terrell, 2002). As transition generated an unprecedented economic insecurity, job insecurity became a crucial issue for many (Linz and Semykina, 2008). Low-educated, young, single individuals and women, especially married women, were more likely to become unemployed (Boeri and Terrell, 2002). Thus, transitional reforms soon produced both economic "winners" and "losers" (Brainerd, 1998; Terrell, 1999).

The adjustment patterns of the output and labor markets differed substantially between the CEE and CIS countries. With a few exceptions, all Central and Eastern European countries experienced a U-shaped pattern of GDP, a large fall in employment early in the 1990s and some decline in labor productivity leading to rapid structural change but also to high unemployment (with the exception of the Czech Republic), much of which was long-term. In contrast, the CIS countries typically faced an L-shaped pattern of GDP during the 1990s and a relatively modest decline in employment with limited sectoral reallocations of labor. Here, however, there was a more pronounced deterioration in labor productivity and of real wages, as well as a significantly larger increase in inequality than in the CEE countries (Boeri and Terrell, 2002; Svejnar, 2002). Overall, while the labor market adjustment process took the form of larger declines in employment in the CEE countries, it typically occurred through real wage declines in the CIS. And only as transition progressed, unemployment began to increase gradually also in the CIS countries (Svejnar, 2002).

A large literature on the optimal speed of transition has studied the speed with which an economy restructures and destroys the old jobs in the state sector (see, for example, Boeri, 2000 for a review). However, by focusing on speed and thus distinguishing essentially between a "big bang" versus a more "gradualist" approach, this literature fails to explain some key differences in the adjustment processes in the CEEC and CIS (Boeri and Terrell, 2002). Alternative explanations relate the differences in performance to differences in institutions. In particular, social safety nets and nonemployment benefits may have prevented the decline of wages in Central and Eastern Europe by setting floors to them (Boeri and Terrell, 2002). In addition, weaker legal systems and poor enforcement of laws and regulations in the CIS have probably encouraged both a profound lack of transparency in government and corporate recklessness, which in turn facilitated the spreading of corruption and rent-seeking behavior (Svejnar, 2002; Roland, 2002). In general, the literature stresses the advantages of adopting a political economy perspective and of taking into account also the role of noneconomic institutions, in order to explain the adoption and consequences of different policy 
models in each country (Roland, 2002). In this paper we follow this approach to study the determinants and evolution of public support for transitional reforms.

\section{Data and empirical model}

\section{a) Descriptive evidence and measurement issues}

The data used in this paper come from the New Barometer Surveys (New Democracy Barometers). These are representative surveys of the populations in transition countries consistently collected over time by the Centre for the Study of Public Policy (CSPP) at the University of Aberdeen and the Paul Lazarsfeld Society, Vienna.

As each survey round contains a large number of common questions, which are maintained across time and countries, the set of available surveys constitutes a unique dataset that allows meaningful cross-country comparisons across several years. This allows us to identify trends in political and economic transformations and also, given the composition of the questionnaires, to analyze the determinants of individual attitudes in the face of such changes. Surveys are undertaken independently from governments and face-to-face interviews are performed by trained interviewers working for established national research institutes in the national language (with the exception of the Baltic countries, Belarus and Ukraine, in which cases Russian was also used). The survey includes nationwide multistage random samples of around 1,000 respondents per country (in Russia - around 2,000) over 18 years old.

We have merged several waves of the New Europe Barometer, the New Russia Barometer and the New Baltic Barometer data. The result is a pooled cross-section dataset for 14 transition economies, with surveys taking place in several waves between 1991 and 2004. Ten countries in our sample became members of the EU with the 2004 or 2007 enlargements (Bulgaria, Czech Republic, Estonia, Hungary, Latvia, Lithuania, Poland, Romania, Slovakia and Slovenia), Croatia is currently a candidate for EU membership, while three countries are members of the CIS (Belarus, Russia and Ukraine).

The set of explanatory variables employed in the regressions below includes standard socioeconomic indicators, such as gender, age, education, marital status, urban residence, employment status and household income. We supplemented these with data on macro-economic variables and political institutions. In the final sample we include all individuals with non-missing information on the key explanatory variables. Table A1 in the Appendix presents sample size by country. Definitions of the variables are given in Table A2. 
The New Barometer Surveys include several questions on the degree of individual support (or opposition) towards the process of transition. For the purposes of this paper, we focus on the following sets of questions, which were included in all surveys:

Economic evaluation:

Q.1 "Here is a scale for ranking how the economy works (from +100 at top to -100$)$.

(a) Where on this scale would you put the socialist economy before the revolution of 1989 / perestroyka?

(b) Where on this scale would you put our current economic system?"

\section{Political evaluation:}

Q.2 "Here is a scale for ranking how our system of government works (from +100 at top to -100 ).

(a) Where on this scale would you put the former communist regime / political system before perestroyka?

(b) Where on this scale would you put our current system (with free elections and many parties)?"6

\section{[Insert Figure 1]}

As a first step, we examine the patterns of responses to these questions across time and countries. Figure 1 shows the proportion of positive, negative and zero evaluations of past and present economic (left panel) and political (right panel) systems for 1993 and 2004. For the economic system, a majority of respondents valued negatively the current system in 1993, while it gave positive evaluations in 2004. For the past economic system, a majority of respondents gave positive scores both in 1993 and 2004. The picture is somewhat different for the political system, as a majority of individuals evaluates positively both the past and the present system in both years, and the proportion of positive answers increases in 2004. Note also that neutral (zero) evaluations constitute only a small proportion in the overall poll.

In principle, there are several alternative ways in which the evaluations presented above can be used to formulate an appropriate dependent variable for our analysis. For instance, should we focus only on individual judgments about the present system? Or instead on a comparison between evaluations for the present and the past? As we are interested in modeling the support for transition and reforms, a relative measure seems intuitively more appropriate, as it would reflect a comparison between the current and the past systems. Moreover, the answers to these questions may be related, inter alia, to whether the revision of opinions about the previous regime reflects a (selective)

\footnotetext{
${ }^{6}$ Note that the questions have been framed in accordance with country-specific situations. For example, "free elections and many parties" are not mentioned in the Russian questionnaire, and the questions are only about "the current system" and the economic or political systems "before perestroyka".
} 
forgetfulness of the past or a delusion about the present or, indeed, a mixture of both. Our a priori is that judgments about the past are meaningful, and that evaluating the past more favorably is part of the same process that results from a delusion about today's experience. Accordingly, a judgment about the past is not only a historical assessment, but it also conveys information about the evaluation of the present system. In other words, statements about the past and the present are not independent of each other, but rather reinforce each other. To take this into account we compute our dependent variable by taking the difference (or "distance") between the responses to Question (b) (present) and to Question (a) (past) for the economic and political systems, respectively. Thus, a larger positive (negative) difference implies a larger positive (negative) assessment of the present regime relative to the former one (in the economic or governmental dimensions, respectively). The larger is this distance, the more an individual is positive about the current state of the economy or polity, relative to the past, and thus, we assume, the more supportive he or she is for the reforms that have been adopted.

In this context, it is important to note that differences in responses across countries may also arise due to different interpretations of the reference scale $(-100 ;+100)$ in different countries and by different individuals, as they may be related to country-specific factors, such as culture. To this aim, we also standardize our dependent variable dividing it by its country (and year) specific standard deviation and control for country-specific effects in the regressions below. In this way we weight individual responses by a country and year specific variance, thus giving more weight to countries with relatively homogenous responses. A related problem that arises when using subjective data is that individual responses may be affected by several factors, such as the ordering of the questions in a survey, the exact wording of the questions or individual differences in the perceptions of the scale, which may introduce a measurement error (Bertrand and Mullainathan, 2001). Note that the questions on the economic and political systems in our survey are usually asked at the beginning of the corresponding sections on the economy and public affairs, before the questions on the personal (or family) economic situation or on political preferences. Note also that taking differences across individual answers for the same person may difference away individual-specific and evaluationinvariant factors such as pessimism or different individual perceptions of the scale, thus potentially reducing the associated biases. In section 7 , we test the robustness of our results also in this respect. ${ }^{7}$

\section{[Insert Figure 2]}

Before proceeding to a more formal analysis, let us take a further look at the evolution of the support variables across time and for the individual countries. Figure 2 shows the developments over

\footnotetext{
${ }^{7}$ In general, we have extensively tested the sensitivity of our main results to alternative definitions of the dependent variable (see below). Overall, our main results were robust to such changes.
} 
time of the support for the present and past systems as well as the corresponding "distance". Support for the past economic system is quite high across 1991-2004, while it is much lower for the past political system (and negative at the beginning of the 1990s). The ranking of both past and present systems also tend to increase over time. Moreover, support for the past economic regime is always higher than for the present. On the contrary, the difference between the evaluations of the past and the present political systems is quite small from 1992 onwards. As a result, our "distance" measure has a U-shaped profile for the economic system, while for the political system it decreases sharply in the very beginning, decreases slowly until 1998 and increases rather slowly afterwards. This Ushaped pattern in the support for economic transition is in line with Blanchard (1997), who argued that public support for reforms is U-shaped, following similar patterns in output and employment, and is also consistent with previous empirical results based on different data. However, we noted that only in a few countries the evolution of support follows the development of GDP over time. It is also worth noting that support for change in the political system ("distance") appears larger than for change in the economic system. This is consistent with political economy approaches which suggest that more popular reforms should be implemented first, and with the observation that democratic reforms preceded economic reforms in all Central and Eastern Europe, since support for democracy was larger than for economic reforms (Roland, 2002).

As these aggregate changes may be driven by changes in the composition of countries in our sample throughout the period, in Figure 3 we plot the evolution of "distance" in different countries. Over 1991-2004, the Czech Republic is the country with the largest support for both the economic and political reforms, ${ }^{8}$ while evaluations of the economic system change are the lowest in Ukraine, Lithuania and Russia and of the political system change - in Ukraine, Russia and Belarus. During 1991-1995, the support was the lowest in Ukraine and Belarus, during 1996-2000 - in Ukraine and Lithuania (economic reforms) and Ukraine and Russia (political reform), while in the beginning of 2000s it was the lowest in Russia and Slovakia for both. Figure 3 also suggests that support for the economic system change is increasing in many countries, while support for the political reforms in several countries is even decreasing, but is larger on average.

\section{[Insert Figure 3]}

Finally, in Figure 4 we plot the evolution of our standardized measures of support for transition together with the average of the EBRD Transition Indicators, for the countries included in

\footnotetext{
${ }^{8}$ The highest support in the Czech Republic is remarkably consistent with one of the "political economy puzzles in Central Europe" (Roland, 2002, p. 44), namely, the higher stability of the government of Vaclav Klaus in the Czech Republic (until recently), compared with governments in other transition countries; the fact that the Czech Republic has managed to maintain lower unemployment rates could be one of the potential explanations.
} 
each year sample. While the Transition Indicator was improving during the 1990s, support for transition appears to have been decreasing; only after 2000 there is some evidence of positive comovement. One way to interpret this observation is that during the painful period of large adjustments and restructuring, public support for reforms may have actually decreased, and it may have started to increase only more recently, during the years of sustained growth.

\section{[Insert Figure 4]}

Summing up, on average citizens of many transition countries did not seem to give a favorable evaluation for the economic system they lived in, and they seemed to have regrets for the past. On the other hand, on average, they appeared reasonably satisfied with their current political system, but in some instances they still did not see it as an improvement over the past. This is true, in particular, of the current CIS members, but also several other countries, such as Lithuania, Latvia, Hungary or Slovakia express negative evaluations in certain periods. These findings, however, should not be interpreted as reflecting a desire to return to Communism, as among the respondents who give positive evaluations to the past economic or political system, only about 30 percent would actually agree to "return to communist rule". Nevertheless, the fact that support for transition is so low may appear puzzling, at least prima facie, if we compare these responses with the evolution of most standard macroeconomic and institutional indicators, especially in the new EU member states. But these aggregate differences may be confounded by differences in individual characteristics and transition experiences. Moreover, country-specific macroeconomic policies and institutions may have also affected individual support attitudes. In the sections below we examine the role of these factors. Although some caution will be needed when interpreting some of our results as causal relationships, documenting the role of these factors will hopefully contribute to sheds additional light on the overall political economy of transition.

\section{b) The empirical model}

We model individual support for the economic and political transition assuming that it may be influenced by three sets of explanatory variables. First, standard individual socio-economic characteristics may help to sort out actual or potential "winners", who are likely to support the transition process, from the "losers" who are unlikely to support it. Second, ideology and individual preferences and values (usually unobservable) may also influence individual support for transition, and excluding these variables could potentially confound the results. On the other hand, individual values and preferences are subjective, endogenous variables, likely to be shaped by individual socioeconomic characteristics, the performance of the system and the inherited cultural values. Nevertheless, it is interesting to explore the correlation between these variables and support for 
transition. Third, country-specific indicators for economic performance and institutions are also likely to be correlated with individual support for transition, as they would be in any model of rational political choice.

We begin with the following simple specification of the baseline model:

$$
Y_{i j t}=\beta X_{i j t}+\delta_{j t}+\varepsilon_{i j t}
$$

where $Y_{i j t}$ is our measure of support for transition for individual $i$ in a country $j$ in year $t, X_{i j t}$ is a vector of standard individual socio-economic and demographic characteristics, $\delta_{j t}$ are the interactions between country-specific and year fixed effects and $\varepsilon_{i j t}$ is a random error term, which ideally should not be correlated with the rest of the variables. To analyze cross-country differences we also estimate the model with country-specific effects and time dummies entered separately.

Next, we add to this baseline model a set of variables reflecting individual (subjective) preferences and values. As we noted above, these variables are likely to be endogenous and thus the parameters estimated have to be interpreted with caution, since the estimates are certainly not structural. Nevertheless, this inclusion allows us to measure the correlation between support for transition and, for example, preferences for redistribution or trust in political institutions, which is interesting per se. Overall, as we have access to a rich set of individual characteristics and cultural preferences, and we are also able to control for country-specific effects and trends, we believe that this might increase the reliability of our results with respect to earlier studies.

As a further step, we introduce macro-economic and institutional variables into the baseline model, in order to capture the impact of each country's economic performance and political institutions, and in particular to assess whether these contribute to explain the lower support for transition in the CIS countries:

$$
Y_{i j t}=\beta X_{i j t}+\theta W_{j t}+\mu_{j}+\varphi_{t}+\varepsilon_{i j t}
$$

where $W_{j t}$ are country-specific variables that vary over time, $\mu_{j}$ are time-invariant country fixed effects and $\varphi_{t}$ are year fixed effects.

\section{Who is against reforms?}

\section{a) Determinants of reform evaluations and cross-country differences}

As we argued above, transitional reforms generate economic "winners" and "losers" (Brainerd, 1998, Terrell, 1999). People who would not benefit from or could not adapt to the 
changing environment would probably not be in favor of the transition. For instance, as it has often been remarked, older workers, women and those already unemployed or with obsolete labor market skills can be expected to oppose the transition reforms, as they might fear the decreased social security and increased unemployment risks. Also, individuals who had experienced the labor market under socialism probably have different attitudes than the younger cohorts. On the other hand, young, educated and wealthier individuals are more likely to support the process of transition, as they may benefit from the new opportunities that arise with it. Finally, subjective wellbeing may be affected by specific individual experiences, such as having to endure periods of economic hardship (Guriev and Zhuravskaya, 2009); these experiences are also likely to affect individual evaluations of the transition.

\section{[Insert Table 1]}

Table 1 reports the estimates of the baseline equation (1) for the evaluations of the economic and political systems. In both tables, the dependent variable is "distance", i.e. the ranking of the present system relative to the past one. We first fit the models for the whole period and then analyze it across two sub-periods, "recession" (1991-1998) and "growth" (2000-2004), as individual evaluations may differ in periods with different economic conditions and reform progress. Our main findings are as follows.

First, irrespectively of controlling for interactions between country and year-specific effects or entering them separately, the impact of individual characteristics remains largely the same, and is consistent with the "losers vs. winners" approach. The evaluations given by females, older individuals and those who are unemployed are generally more negative; while those given by graduates from universities or secondary or vocational schools or students, and those living in richer households are more favorable. The effect of urban residence is positive and significant in most of the regressions. There is also a positive and significant cohort effect for those who were 18 years old or younger in 1990 (and thus presumably had not experienced the labor market under socialism). The largest negative impacts are for individuals in their 50s and for the unemployed, while the largest positive effects are for the richest households and for university graduates. Country-specific effects, in general, confirm the descriptive evidence presented above: taking Slovenia as the reference country, individuals in the Czech Republic, Poland and Croatia are significantly more appreciative about transition, whereas those in the CIS countries are generally more negative.

Second, there are several differences between the support for economic and political reforms. While support for change in the economic system was lower in 1990s relative to 2004, support for change in the political system is relatively stable. Note, however, that the composition of the sample with respect to countries changes throughout 1991-2004, therefore, a separate analysis on a country- 
by-country basis is also needed (see below). Also, the impact of most individual characteristics and country-specific effects is larger for the economic reforms than for political reforms (with some exceptions).

Third, the impact of some individual characteristics changes between the 1990s and 20002004. While the effect for females, older individuals, those living in cities and students is stronger in the 1990s, the impact of young cohort, education, single, higher income quartiles and also (for the economic system) of being unemployed is larger during 2000-2004. Also the effect of almost all country dummies is much stronger during the 1990s, which probably is one of the most interesting results of this comparison. During the 1990s, the largest negative country effects on the evaluation of the economic system were in Ukraine, Belarus and Lithuania, while in the 2000s in Russia, Ukraine and Lithuania. For the political system, the largest negative effects in the 1990s were in Ukraine, Russia and Belarus, and during the 2000s in Russia, Latvia and Slovakia. ${ }^{9} 10$

As we mentioned above, a potential criticism against using our measure of distance is that it does not take into account the "absolute" evaluation of the current or of the past system given by the respondents. For instance, the same distance of 70 could characterize someone who likes both the past and the present (past $=30$; present $=100$ ), someone who dislikes them both past $=-100$; present $=-30$ ) and someone who dislikes the past but is reasonably satisfied with the present (past $=-40$; present $=30$ ). These absolute evaluations might contain additional information. To take it into account we follow a classification introduced by Mishler and Rose (1994) and used in later studies by the same authors. Accordingly, we divided our sample in eight different sub-groups as follows. Individuals who give positive evaluations to both the present and past economic (or political) systems are "positive" ("compliant"). Those who are neutral or negative about both the present and past economic (political) systems are "negative" ("skeptic"). Those who evaluate positively the present economic (political) system and negatively or neutrally the past are "pro-market" ("democrat"). And those who are negative or neutral about the present and positive about the past economic (political) system are called "nostalgic" ("reactionary"). Based on this classification, we estimate multinomial logit regressions for the probability to be in one of these groups. Marginal effects from these regressions are presented in Table 2.

\footnotetext{
${ }^{9}$ We have also estimated the baseline model keeping in our sample only those individuals who were older than 18 years in 1990, since they have had an experience of the old system and thus can compare it directly with the new one. The estimates of the rest of the coefficients remained unaffected (with the only exception of the student variable that became insignificant in the equation for the political transition). In addition, we have experimented with excluding Russia or Belarus from the sample, and the main results remained qualitatively the same (all results are available upon request).

${ }^{10}$ Since our dependent variable is, in principle, ordered it is also possible to estimate an ordered probit model. To estimate such a model, we coded our "distance" measure into four ordered categories (from -200 to -100, from -100 to 0 , from 0 to +100 , from +100 to +200 ). The qualitative results were identical to those reported in the text, and are available upon request. However, since the quantitative interpretation for this model would be somewhat more complicated, we chose to present only the OLS results.
} 
Several facts emerge from this table. First, only few individual characteristics are significant for the "positive" and "compliant" groups. Second, the impact of individual characteristics on the likelihood of being "pro-market" and "democrat" is qualitatively opposite to the impact for the "nostalgic" and "reactionary" groups. For instance, the likelihood of being "pro-market" (see column 2) is significantly lower for females, unemployed and pensioners and is decreasing with age. On the other hand, university graduates are 7 percentage points more likely to be "pro-market" relative to those with elementary education, and individuals from the highest household income quartile are 8 percentage points more likely to belong to this group. Looking at the political system and, again, focusing on the group of those who support the change of the system (i.e. "democrats", column 5), we find a very similar impact of most individual characteristics; only the urbanization and pensioner variables become insignificant.

Overall, the results from the multinomial logit analysis reinforce those from the OLS regressions above. Individual characteristics shape the pattern of individual evaluations regarding the economic and political system in a strong and plausible way. Country effects are also large and consistent across different specifications. Most important, this analysis shows that those characteristics that determine individual likelihood to belong to a "pro-market" group go in the same direction as those that drive his or her attitudes towards more positive evaluation of reforms. In other words, those who have higher support attitudes are, consistently, more likely to belong to the "promarket" and "democrat" groups, and vice versa. Therefore, this validation exercise adds credibility to the interpretation of the OLS regressions as modeling support for reforms and for transition.

As an additional exercise we also analyze the determinants of individual evaluations by countries (not reported, but available upon request). Since the composition of the countries' sample changes throughout the period, such country-specific analysis identifies trends in the support attitudes in each country. The individual characteristics included in the regressions were the same as in the baseline model above. The only notable exception is the introduction of a minority dummy for the Baltic states, as ethnic minorities constitute a significant part of the population in these countries (especially in Estonia and Latvia) and the process of transition may have affected them differently from the majority of population. ${ }^{11}$ In general, this exercise reveals some heterogeneity across countries. One of the most interesting facts is that the positive effect of belonging to the young cohort in the overall sample comes mainly from Russia and, to a lesser extent, Bulgaria (for the evaluations of the economic system), and from Estonia, Lithuania and Croatia (for the political

11 For an analysis of labor market performance of immigrants and non-citizens in the new EU member states see Kahanec and Zaiceva (2009). 
system). Females have a stronger opposition to reforms in the Baltic countries. University education does not significantly influence reforms evaluations in Croatia, Romania (economic) and Belarus (political). It is remarkable that unemployment does not appear to influence significantly the extent of support for economic reforms in Russia nor in Belarus. This could presumably be related to the fact that wage arrears rather than layoffs have been prevailing in Russia as a means to reduce the burden of labor costs on firms, and that very few reforms at all have taken place in Belarus. On the other hand, regarding the evaluation of the political system, our results suggest that unemployment is much less important than it is for the economic system, (as it is significant only for Latvia, Bulgaria and Croatia, and marginally for Hungary). As expected, belonging to an ethnic minority has a strong negative effect in all three Baltic countries, with the largest effect in Estonia. This probably reflects the hardship of adjusting to the new system for individuals of Russian origin and their dissatisfaction with their economic situation and political rights. Moreover, the negative minority effect is stronger for the support of the political reforms than of the economic ones. Finally, regarding year dummies, while support for economic transition has generally increased in nine countries out of fourteen from 1991 until 2004, there is less evidence of an increasing trend in the support for the political transition, as the coefficients on the year dummies are positive or insignificant in many cases. ${ }^{12}$ Countries where support for change in the political system was lower in the 1990s than in 2004 include the CIS, Lithuania and, to some extent, Hungary.

\section{b. The importance of individual experiences and preferences}

In the context of our analysis it would be desirable to control for individual heterogeneity in preferences, transition experiences and ideology. In this section, we exploit the richness of the data at our disposal to do so; in particular we take into account the information on often unobserved aspects of individual heterogeneity, such as preferences.

To introduce this analysis, we first briefly examine the implications that four subjective characteristics might have for our model. (i) As we noted above, the experience of individual hardship during the transition process may influence personal happiness (Guriev and Zhuravskaya, 2009) and thus also affect individual evaluations of the process of transition. (ii) Also the speed at which reforms were actually implemented may influence individual evaluations of the process. As it has been suggested in the literature on the optimal speed of transition (Aghion and Blanchard, 1994) and on the desirable sequencing of reforms (the "big-bang vs. gradualism debate", see, e.g., McMillan and Havrylyshyn, 2004, Murphy et al., 1992 and Roland, 2002), reforms can be perceived

\footnotetext{
${ }^{12}$ Note that for Croatia we have information only for 1992 and 1993, with the latter being the reference year.
} 
to go too fast or too slow, and in each case an individual assessment of the reform process may become more unfavorable. (iii) The extent of corruption in a country may also affect negatively individual attitudes towards the process of reforms. (iv) As communism is believed to have shaped cultural attitudes towards redistribution (Alesina and Fuchs-Schundeln, 2007), it is likely that preferences for a more active role of the state in redistributing resources may be negatively correlated with individual attitudes towards the process of transition from communism. Thus, it may be important to control for these aspects in our baseline regression model.

In addition, following the literature on the importance of informal institutions and social capital, we have also included in the analysis different measures of trust, although - as we noted in our previous discussion - many of these variables are subjective measures and are likely to be endogenous. In such cases, regression result will only be interpreted as measures of partial correlation - which in any case provides useful additional insights.

\section{[Insert Table 3]}

In Table 3 we show the results of introducing these variables into the baseline model for the economic (upper panel) and political (lower panel) evaluations. Results for the other covariates are omitted in order to save space, but are available upon request. First, to proxy for individual hardship experienced during the transition, we construct two indicators, both of which refer to the year before the interview. The first variable (see column 1), measures the total number of weeks, during which a person was either unemployed or was not paid salary in full or a payment was delayed. The second variable (column 2), is a so-called destitution scale, constructed on the basis of several responses to more specific questions in order to reflect the frequency a person or her family had to live without food, heating, electricity or clothes. ${ }^{13}$ The estimated coefficients for both variables are negative, as we would expect from the related literature: the more intense is the experience of an economic hardship, the lower becomes the support for transitional reforms. Note also that when introducing these variables the young cohort dummy becomes insignificant.

Regarding the speed of reforms, respondents were asked in 1995 and 1996 whether they thought that the reform process was going "too fast", "too slow" or "at the right speed". The results in column (3) indicate that the perceptions of a "wrong" speed of reforms ("too high" or "too slow") influence negatively individual attitudes towards transition. Interestingly, a stronger individual resistance is associated with the perception of an excessive speed. Also in this case the young cohort dummy becomes insignificant.

Political preferences or values may be another potentially omitted variable, especially in the equation for political reforms. We attempt to proxy for a preference towards dictatorship, using the

\footnotetext{
${ }^{13}$ This variable was already available in the dataset.
} 
following two variables. Survey respondents were asked whether they would approve if the Parliament was suspended and whether it would be better "to get rid of Parliament and elections and have a strong leader". Results in columns (4) and (5) indicate that such preferences are indeed significantly and negatively correlated to support for transition, both in the economic and in the political dimensions.

We then attempt to control for the extent of corruption in a country by generating a variable that equals 1 if an individual thinks that most or almost all "public officials [in the country] are engaged in bribe-taking and corruption" and equals zero if he thinks that "very few" or "less than half public officials are corrupt". Unfortunately, this question was asked only in 2001 and 2004 and the sample size drops substantially. Nevertheless, as indicated in column (6), the corruption variable is significant and has the expected negative sign for both economic and political attitudes. The coefficients on the other individual characteristics remained fairly robust.

The opinion that the state should engage more actively in redistributing resources across individuals may originate either as a cultural preference or as a reaction to current unfavorable economic circumstances. In any case, preferences for more redistribution are probably correlated with negative attitudes towards the transition from communism. We attribute these preferences to those who agree with the statement "Incomes should be made more equal so there is no big difference in income" (as opposed to the statement "Individual achievement should determine how much people are paid"): as shown in column 7, these respondents also show significant less support for transitional reforms.

In the related empirical literature, age is often used as a proxy for ideology. However, age could measure either the increased hardship imposed by transition on older individuals with obsolete skills, or, indeed, the fact that their ideological values might have been shaped by communist institutions and culture. In fact, as we have shown, older individuals are particularly negative about the transition process and are significantly more likely to belong to the "nostalgic" and "reactionary" groups. In addition, in column (8) we include a variable, which indicates whether the respondent or anyone of his family were formerly members of the Communist Party. As expected, this variable is significant and has a negative sign in both tables, suggesting that past party membership is negatively correlated with individual support for transition. At the same time, the sign and significance of the age dummies is reduced and the young cohort dummy becomes insignificant. This validates our suggestion that age is also - but not only - a proxy for ideology.

Finally, we have introduced several variables that measure the diffusion of trust towards political institutions and people (columns 9-12). Our findings suggest that trust towards parties, parliament, the president or other people is associated with a more positive assessment of the transition. 
In general, while this descriptive exercise sheds additional light on the characteristics of those who are against transitional reforms, the sign and significance of other individual characteristics remain fairly robust to the introduction of additional variables and to the related changes in the composition and size of the sample. The CIS countries (and in some cases Lithuania) always have the lowest average support attitudes. In the next section we search for potential explanations of the lower level of support in the CIS countries.

\section{Why is support for transition lower in the CIS countries?}

A common finding from the previous sections is that the average level of support for reforms, in both the economic and political dimensions, has been different across countries, and reached its lowest in the CIS countries. Given the diversity of the initial conditions, of the objectives and sequence of reforms, of the paths of political development and of economic performance, it would be surprising if citizens from different countries would converge to the same evaluations of their countries' experiences. But why are negative evaluations concentrated in the CIS?

The CIS and CEE countries shared the experience of a socialist economy with relatively secure jobs, officially low inequality and equal pay, but also low motivation and low individual responsibility. There were, however, several important differences between these countries, including those in their history and in their democratic achievements before socialism (Svejnar, 2002). First, most Central and Eastern European countries had stronger historical and geographic ties and trade relations with Western Europe. These ties - which already provided a closer cultural proximity between CEE countries and those in Western Europe - were suddenly "rejuvenated" when the perspective of adhesion to the EU became concrete, after German reunification. Second, the CIS countries have gone through a longer and more intense communist experience relative to most CEE countries: this experience lasted seven decades in the CIS, five in the Baltic countries and four in CEE. Third, economic reforms have been implemented using different strategies and policies, and as a result the performance of the CIS and CEE countries has also differed. Finally, also the path of political liberalization has been different, so much so that in 2004 the Freedom House Ranking of political rights and civil liberties still ranged between "not free" for Belarus and "partly free" for Russia and Ukraine to "free" for all the CEE countries. Several explanations for these differences in economic performance have been suggested in the literature. They include the role of larger safety nets and non-employment benefits in the CEE countries, better legal systems and enforcement of laws and regulations, a lower degree of corruption and rent seeking than in the CIS. On the basis of 
this literature, this section explores several potential explanations for the lower support attitudes found in the CIS. Although this list of potential explanations is surely not exhaustive, in this section we explore the role of individual experiences and preferences (Section 5a) and that of countryspecific economic and institutional factors (Section 5b).

\section{a. Individual experiences, values and preferences}

In order to explore the reasons for the lower support in the CIS countries we again add to our baseline model additional variables, measuring individual experiences, values and preferences. If these new variables contribute to explain the lower levels of support in the CIS countries, we should observe a significant coefficient on these additional terms and at the same time the dummies for Russia, Ukraine and Belarus should either decrease in magnitude or become insignificant. Consistently with our review of the literature, candidate variable for this analysis are individual preferences for redistribution and income equality, for state's responsibility over individuals' material security and for state ownership, as well as for a secure (but also less rewarding) job.

\section{[Insert Tables 4 and 5]}

Tables 4 and 5 show the estimation results for both economic (Table 4) and political (Table 5) support attitudes. The other individual characteristics are the same as in the baseline model. Results in each odd-numbered column should be compared with those in the adjacent even-numbered column with the same sample size. Since the results are qualitatively similar in both tables, in what follows we will discuss them jointly. The essential finding is that the coefficients on the CIS country dummies decrease sharply when we introduce in the regression a variable measuring preferences for state ownership (columns 12 vs.11, in both Tables). This result is entirely in line with the finding that a majority of individuals are not satisfied with privatization and want to revise it (Denisova et al., 2009). Lack of trust in political institutions also contributes, albeit to a smaller extent, to explain the lower support attitudes in the CIS (as may be seen from comparing, in both Tables, columns 1 vs. 2; 3 vs. 4 ; and 5 vs.6).

In addition, we also introduced some variables already included in Table 3, such as transitionrelated hardship, opinions on the speed of reforms and on corruption, preferences for a strong leader and trust in political institutions. We briefly comment on the consequences of this introduction, without reporting the detailed empirical results (which are available on request). In reference to transition-related hardship, we found that including the destitution scale decreases the coefficients on the CIS country dummies, while the number of weeks without pay or job does not. This seems plausible, as it suggests that living without appropriate food and heating matters more than the 
number of weeks without pay or job. The particular features of labor hoarding and high wage arrears in Russia reinforce this interpretation. Second, including opinions on the speed of reforms lowers the coefficients for all the CIS country dummies in the equation for economic reforms and for Russia and Ukraine in the equation for political reforms. Third, also adding preferences for a dictatorship reduces the magnitude of all the CIS dummies, while the inclusion of individual perceptions of corruption reduces mostly the dummies for Russia.

Overall, a preference for state ownership, lack of trust in political institutions, a preference towards dictatorship, a reaction against the excessive speed of reforms and perceptions of corruption (especially in Russia), are factors that contribute to explain the lower support for transition found in the CIS countries. However, although the coefficients on the CIS dummies are diminished in size, they do not become insignificant after the inclusion of these additional terms. This suggests that there are other important factors that should be explored further.

\section{b. Country-specific performance and institutions}

To complete the picture, we now focus on macro-economic variables and institutional indicators of the quality of the economic and political system. Note that in this case we pool together individual and country-level variables and standard errors have to be corrected accordingly. The role of institutions and policies in affecting individual attitudes in post-communist countries has been documented in the literature (see, among others, Denisova et al., 2009; Guriev and Zhuravskaya, 2009). For example output growth, lower income inequality, less corruption and better governance could open up opportunities for improvements for many individuals and thus could be associated with a greater support for reforms. On the other hand, as argued by Rodrik (1995) and Fidrmuc (1999), especially at the beginning of transition high unemployment may actually signal the need for more radical reforms and thus paradoxically reinforce support for reforms. Therefore, the sign on the unemployment variable is a priori ambiguous.

Again in this section we focus on how the introduction of these new variables in the baseline model affects the coefficients of the CIS country dummies. Results are reported in Tables 6 and 7 for the economic and political systems, respectively.

\section{[Insert Table 6 and Table 7]}

In order to facilitate comparisons, column (1) in both tables reproduces the results of the baseline regressions (Table 1, columns 1 and 5). Individual controls are included in all regressions, but are not reported to save space. We first introduce sequentially three traditional macro-economic control variables: aggregate unemployment, GDP per capita and inflation. When added sequentially, 
none of these macroeconomic variables is statistically significant, although adding inflation eliminates the significance of the CIS dummies, which suggests that this variable may be affecting negatively the level of support for transition in the CIS (equation not reported in the Tables). More persuasive results appear when we introduce also the Democracy Index from the Polity IV database (column 2 and $3^{14}$ ): this raises the absolute value and the significance of the coefficients on the CIS dummies (although the coefficient on Ukraine remains insignificant in the equation for the political system).

Two features of the equations in column (2) require specific comments. The first is about why the macro-economic variables are generally not-significant. ${ }^{15}$ On this point, there may be several reasons. One is that these variables are included in addition to country and year-specific effects, which might better capture the changes in the macro environment. A second reason is that, in reference to unemployment, people might care more about their own performance than about aggregate unemployment. A third reason may be that left- and right-wing individuals might place different weights on unemployment vs. inflation. ${ }^{16}$ As argued by DiTella and MacCulloch (2005), left-wing individuals may care more about unemployment, while right-wingers care more about inflation. However these differences may cancel out when averaging across left and right-wing individuals, as is done here. A fourth reason is that high unemployment might actually signal the need for more reforms (as in Rodrik, 1995), rather than the failure of past ones.

A second set of comments is required to explain why, in both Tables, a higher level of democracy appears to be negatively related to support for transition. Our preferred explanation is based on the observation that, for the majority of countries, this indicator does not vary much during this period, with the exception of Romania (where it is increasing) and Belarus (where it is decreasing). Thus, this variable acts almost as a dummy, essentially separating (with the two exceptions just noted) EU from non-EU members, and is thus collinear with the CIS country dummies. ${ }^{17}$ Alternative explanations could follow the one proposed by Guriev and Zhuravskaya (2009), who find a negative relation between democracy and the happiness index, and also by Denisova et al. (2009), who show that, in more democratic countries, individuals who experience economic hardship during transition are more likely to favor re-nationalization.

\footnotetext{
${ }^{14}$ In column (3) we have also added for the lagged EBRD index of transition reforms, to include an indicator of the overall progress of transition. This is only marginally significant in the equation measuring economic support (Table 6) and, in this case, it renders the unemployment rate also significant, with the expected negative sign.

${ }^{15}$ With the exception noted in the previous footnote.

${ }^{16}$ In addition, there might be a relevant discontinuity in the individual reactions to inflation, as many countries in our sample where characterized by hyperinflation in the early 1990s.

${ }^{17}$ This is consistent with the fact that including the Democracy Index has the effect of increasing the absolute value of the CIS country dummies.
} 
Holding the level of democracy constant, income inequality may be another reason why people have negative attitudes towards the economic or the political system. In line with Guriev and Zhuravskaya (2009), we find that the Gini index has a large and significant negative effect in both Tables (column 5). This equation is to be compared with that in column 4, which is run on the same sub-sample for which the Gini index is available: the effect of including the Gini index on the CIS country dummies are either irrelevant or marginal. ${ }^{18}$

Finally, in order to account for the changing quality of political institutions, we added the World Bank Governance Indicators (column 7). This equation is to be compared with that in column 6 , which is run on the same sub-sample for which the Governance indicators are available. The results reported in Table 6 are remarkable: the inclusion of these indicators eliminates the significance of all the CIS country dummies in the equation for the economic transition. (In Table 7, for the political transition, the coefficients on the CIS country dummies are insignificant already in the sub-sample of columns 6). This suggests that the lower quality of political institutions explains a good measure of the lower support for the new economic regime in the CIS countries. In both Tables, the Governance Indicators have a significant effect on economic and political attitudes. Especially political stability and the rule of law are associated with higher support for both the economic and the political regime.

\footnotetext{
${ }^{18}$ To take into account other measures of the deterioration of public goods, we also included several other indicators, such as the number of hospital beds, life expectancy, number of doctors, public expenditures on health and education, mortality rates of children, immunization rates and enrollment rates in primary, secondary and tertiary education. Several of these indicators declined significantly in the CIS countries during the 1999s (see Svejnar, 2002). However, the inclusion of these variables does not in general reduce the magnitude or significance of the CIS country dummies (detailed results available on request). We also included the Freedom House Ranking of Political Rights Indicator as an additional potential explanatory variable. This variable was tested with or without contemporaneous inclusion of the Democracy Index, but was generally not significant and did not change the value or significance of the other variables.
} 


\section{Robustness checks}

In this section we briefly present several additional sensitivity checks. As many of our results suggest that individual characteristics influence in the same way the evaluation of the economic and the political system, we examined the correlation between these evaluations, which in fact is quite high (raw correlation $=0.63$ ). We thus run also a seemingly unrelated regressions $(\mathrm{SUR})$ model, which fully confirms the results of the OLS estimates, although there is some gain in efficiency for individual coefficients (results are not reported, but available on request).

Second, we have also estimated the baseline models for both the economic and political system using non-standardized distance as a dependent variable (see columns 1 and 2 in Table 8). The results are qualitatively unchanged from the baseline model with standardized dependent variable (column 1 and 5 in Table 1), but can now be interpreted quantitatively in terms of corresponding points on the scale from -200 to +200 . For example, university graduates assign on average 21 (27) additional points to the evaluation of the economic (political) system, relatively to the reference category of those with at most elementary education.

\section{[Insert Table 8]}

Third, we have used a different binary dependent variable, equal to 1 if someone gives higher evaluations to the present than to the past system (columns 3 and 4). Again, the results are qualitatively identical, both for the individual characteristics and for the country and year dummies. Finally, in column 5, we define the dependent variable equal to 1 for those who agree with the statement "We should return to Communist rule". Note that in this case the sample size drops and thus the composition of the sample changes. In general, however, the characteristics that affect positively (or negatively) the probability of agreeing with this statement are the same as those that decrease (or increase) support for transition.

Thus, we are confident that our results remain robust to the use of different estimators, to alternative measures of the dependent variable and to changes in the composition of the sample.

\section{Conclusions}

As the recent EBRD Life in Transition survey remarks, "17 years of transition have taken a toll" (EBRD, 2007b). Indeed, there is a certain "transition fatigue" in the region, a discontent with transitional reforms, which could be also responsible for the more frequent changes of government 
which took place in several countries in the more recent years. In this paper we document the extent of this discontent in 14 transition countries during 1991-2004 and analyze its determinants.

We find that the overall support for change in both the economic and political systems has been relatively low and heterogeneous across different interest groups and countries. There has been an increasing trend in support for the economic changes in many countries, while public support for political reforms has been higher and more stable than for the economic reforms. This is consistent with the political economy approach that suggests that more popular reforms should be implemented first, and with the observation that democratic reforms preceded economic reforms in all Central and Eastern Europe, since support for democracy was larger than for economic reforms (Roland, 2002). Lower support for reforms is found, in line with the literature, among the older, less educated, unemployed and poor individuals and among females, that is those who were more likely to "lose" from transition in relative terms, and these negative effects are generally stronger during the period of recession in the 1990s. Support for transitional reforms has in general been lower in the CIS countries. The effects of almost all country dummies are stronger during the 1990s.

Our main findings remain robust to changes in the definition of the dependent variable, and to specification and sample changes. We also find that the same factors which are related to an aversion or lower support for transition are also positively related to a willingness to return to communism. However, only one-third of those individuals who evaluate the past socialist economy or communist system positively, would actually agree to do so.

We find evidence that economic difficulties experienced during the transition, individual preferences towards dictatorship or redistribution of incomes, opinions on corruption, ex-Communist party membership and less trust for politicians or other people, are associated with lower support for the transition process. Also, those who think that the reforms were conducted too fast are more likely to oppose the transition.

Finally, we tried to explain why attitudes towards the experience of transition have been so markedly lower in the CIS countries. We find evidence that, at the individual level, a preference for state ownership, lack of trust in political institutions, a preference towards dictatorship, a reaction against the excessive speed of reforms and perceptions of corruption (especially in Russia), contribute to explain the lower support for transition in the CIS countries. At the aggregate level, the lower quality of political institutions, measured particularly in reference to political stability and to the rule of law, explains a good part of the lower support for economic reforms in the CIS countries. 


\section{References}

Aghion, P. and Blanchard, O.J. (1994). On the Speed of Transition in Central Europe. NBER Macroeconomics Annual: 283-319.

Alesina, A. and Fuchs-Schuendeln, N. (2007). Good Bye Lenin (Or Not?). The Effect of Communism on People's Preferences. American Economic Review 97: 1507-28.

Bertrand, M. and Mullainathan, S. (2001). Do People Mean What They Say? Implications for Subjective Survey Data. American Economic Review 91 (2): 67-72.

Blanchard, O.-J. (1997). Clarendon Lectures: The Economics of Transition in Eastern Europe. Oxford University Press, Oxford.

Boeri, T. (2000). Structural Change, Welfare Systems and Labor Reallocation. Oxford: Oxford University Press.

Boeri, T. and K. Terrell (2002). Institutional Determinants of Labor Reallocation in Transition. Journal of Economic Perspectives 16 (1): 51-76.

Brainerd, E. (1998). Winners and Losers in Russia's Economic Transition. American Economic Review 88 (5): 1094-1116.

Campos N. and F. Coricelli (2002) "Growth in Transition: What We Know, What We Don't, and What We Should". Journal of Economic Literature, XL, September, pp.793-836.

Denisova, I., Eller, M., Frye, T. and Zhuravskaya, E. (2009). Who Wants to Revise Privatization and Why? The Complementarity of Market Skills and Institutions. American Political Science Review, 103: 284-304.

Easterlin, R.A. (2009). Lost in Transition: Life Satisfaction on the Road to Capitalism. Journal of Economic Behavior and Organization 71 (2): 130-45.

EBRD (2007a). Transition Report: People in Transition. European Bank for Reconstruction and Development, London, UK.

EBRD (2007b). Life in Transition. European Bank for Reconstruction and Development, London, UK. (http://www.ebrd.com/pubs/econo/lit.htm)

Fernandez, R. and Rodrik, D. (1991). Resistance to Reform. Status Quo Bias in the Presence of Individual-Specific Uncertainty. American Economic Review 81: 1146-55.

Fidrmuc, J. (1999). Unemployment and the Dynamics of Political Support for Economic Reforms. Journal of Policy Reform 3: 139-59

Fidrmuc, J. (2000). Political Support for Reforms: Economics of Voting in Transition Countries. European Economic Review 44: 1491-1513.

Guriev, S. and Zhuravskaya, E. (2009). (Un)Happiness in Transition. Journal of Economic Perspectives, 23(2): 143-168.

Hayo, B. (2004). Public Support for Creating a Market Economy in Eastern Europe. Journal of Comparative Economics 32: 720-44.

Kahanec, M. and Zaiceva, A. (2009). Labor Market Outcomes of Immigrants and Non-Citizens in the EU: An East-West Comparison. International Journal of Manpower, 30 (1+2): 97-115.

Kim, B-Y. and Pirttilä, J. (2006). Political Constraints and Economic Reform: Empirical Evidence from the Post-Communist Transition in the 1990s. Journal of Comparative Economics 34: 446-66. 
Landier, A., Thesmar, D. and Thoenig, M. (2008). Investigating Capitalism Aversion. Economic Policy, July: 465-97.

Lazar, O., Mishler, W., and Rose, R. (2007.) What is the Effect of Globalization on Support for Market Economies in Post-Communist Europe? University of Aberdeen, Centre for the Study of Public Policy, Studies in Public Policy No. 421.

Linz, S.J. and A. Semykina (2008). How Do Workers Fare During Transition? Perceptions of Job Insecurity Among Russian Workers, 1995-2004. Labour Economics 15: 442-58.

Mayda. A.M. (2006). Who Is Against Immigration? A Cross-Country Investigation of Individual Attitudes toward Immigrants . Review of Economics and Statistics 88 (3): 510-30.

McMillan, J and Havrylyshyn, O. (2004) Reform: What Pace Works. Finance and Development, September, 34-41.

Milanovic, B; and Ersado, L. (2008). Reform and Inequality during the Transition: An Analysis Using Panel Household Survey Data, 1990-2005. World Bank Policy Research Working Papers no. 4780.

Mishler, W. and Rose, R. (2000a). Political Support for Incomplete Democracies: Realist vs. Idealist Theories and Measures. University of Aberdeen, Centre for the Study of Public Policy, Studies in Public Policy No. 333.

Mishler, W. and Rose, R. (2000b). Regime Support in Non-Democratic and Democratic Contexts. University of Aberdeen, Centre for the Study of Public Policy, Studies in Public Policy No. 336.

Mishler, W. and Rose, R. (2002). Learning and Re-Learning Regime Support: The Dynamics of Post-Communist Regimes. European Journal of Political Research 41: 5-36.

Mishler, W. and Rose, R. (2008). A Two-Way Street in Popular Support for New Regimes: The Political Economy of Post-Communist Transitions. University of Aberdeen, Centre for the Study of Public Policy, Studies in Public Policy No. 441.

Murphy, K., Schleifer, A. and Vishny, R. (1992). The Transition to a Market Economy: Pitfall of Partial Reform. Quarterly Journal of Economics 107(3) (August): 889-906.

Rodrik, D. (1995) The Dynamics of Political Support for Reforms in Economies in Transition. Journal of Japanese and International Economics 9: 403-25.

Roland, G. (2002) The Political Economy of Transition. Journal of Economic Perspectives, 16(1): 29-50.

Rose, R. (2007) Learning to Support New Regimes in Europe. University of Aberdeen, Centre for the Study of Public Policy, Studies in Public Policy No. 424.

Rose, R. and Mishler W. (1994) Mass Reaction to Regime Change in Eastern Europe: Polarization or Leaders and Laggards? British Journal of Political Science, 24: 159-182.

Rovelli, R. and Zaiceva, S. (2009) Transition fatigue? Cross-country evidence from micro data. IZA Discussion Paper No. 4224.

Scheve, K. F. and Slaughter, M. J. (2001). Labor Market Competition and Individual Preferences over Immigration Policy. Review of Economics and Statistics, 83:133 - 45.

Svejnar, J. (2002). Transition Economies: Performance and Challenges. Journal of Economic Perspectives 16 (1): 3-28.

Terrell, K. (1999). Worker Mobility and Transition to a Market Economy: Winners and Losers, in: New Markets, New Opportunities? Economic and Social Mobility in a Changing World. Nancy Birdsall and Carol Graham (eds.), Washington DC, Brookings Institution, Ch. 7. 
Figure 1: Evaluations of the economic and political systems in 1993 and 2004

Economic System

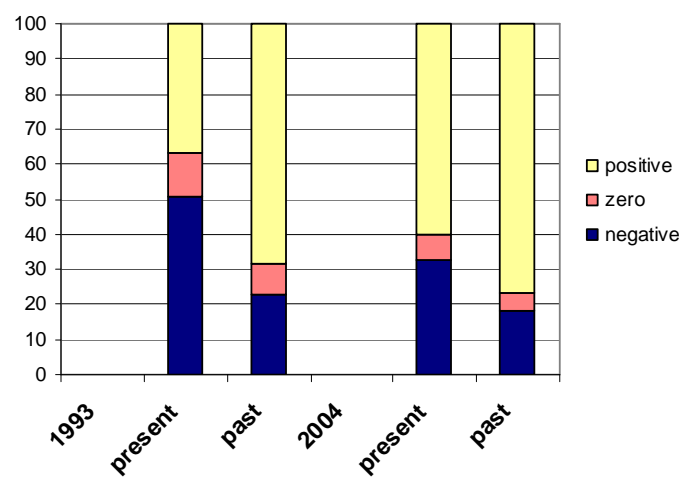

Political System

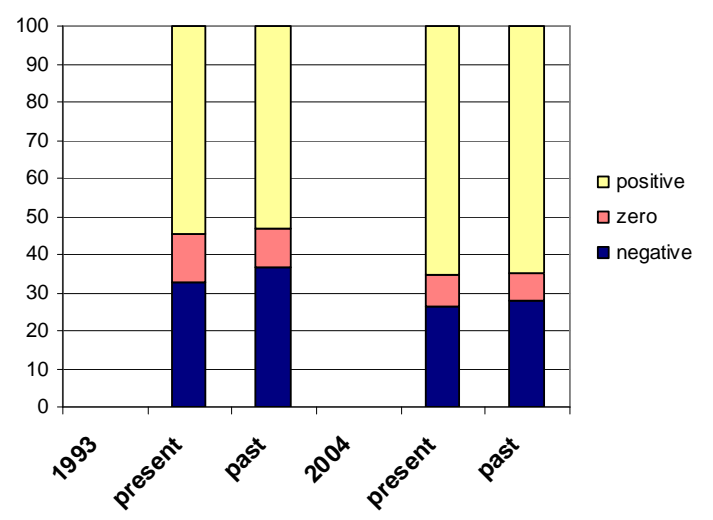

Source: Authors' tabulations from the New Barometers data. Sample includes all individuals.

Figure 2: Dynamics of Support, 1991-2004

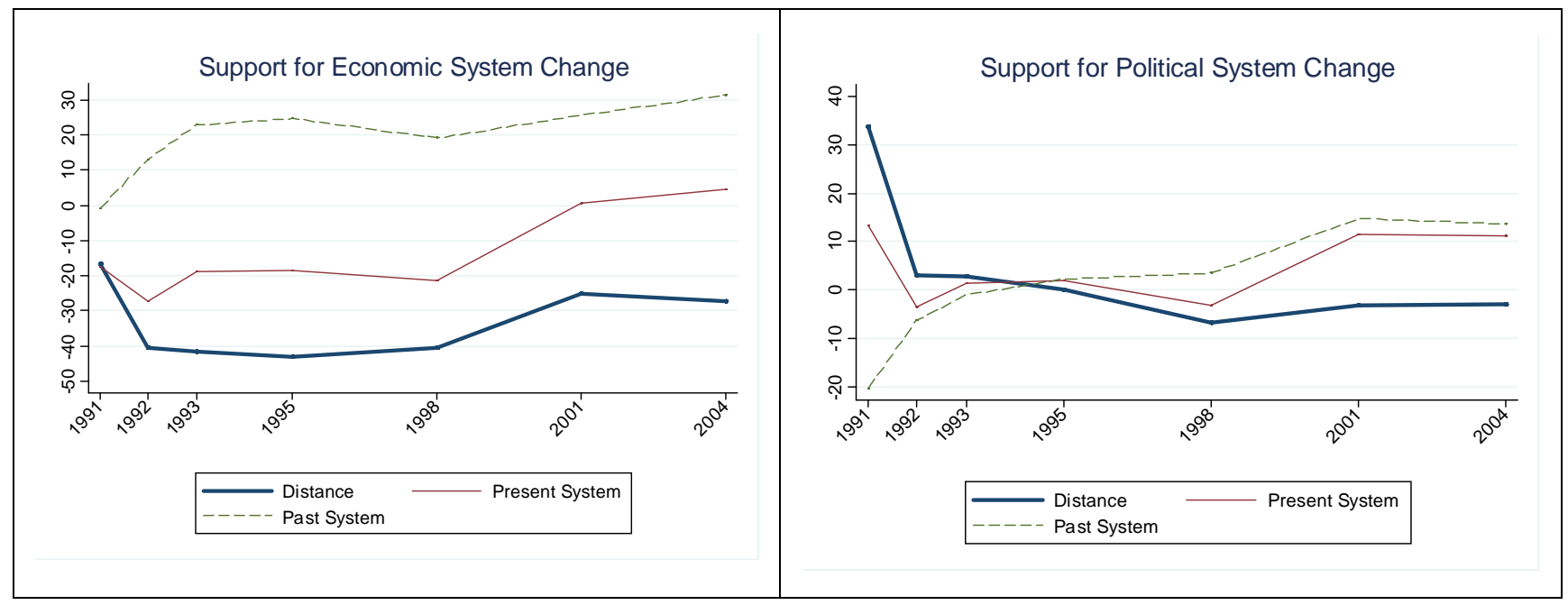

Source: Authors' tabulations from the New Barometers data. See text and Appendix for definition of distance.

Notes: 1996 and 2000 are excluded, since only Russia and the Baltic countries are available for these years. Sample includes all individuals. 
Figure 3: Support for change in the economic and political systems, by country

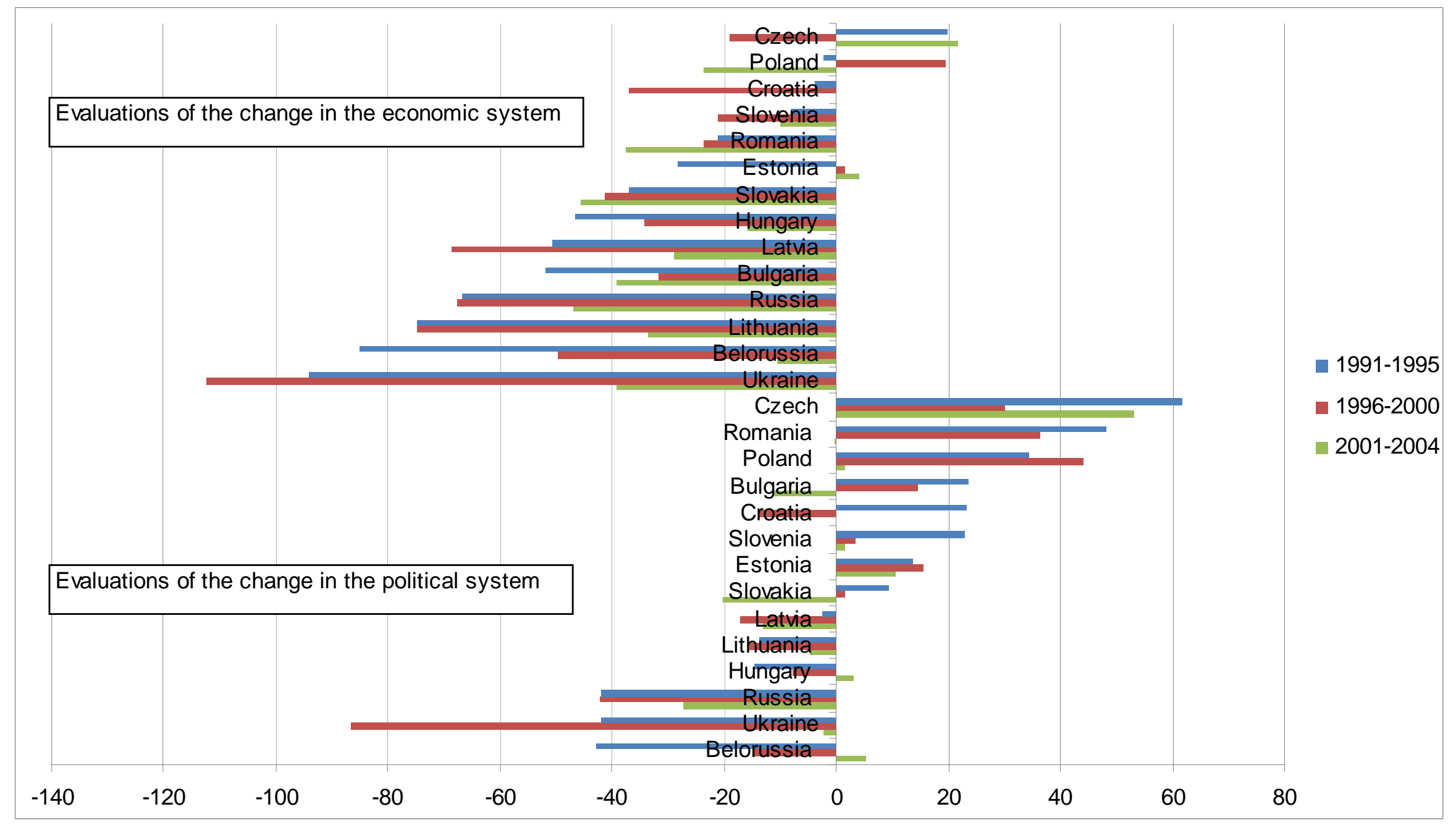

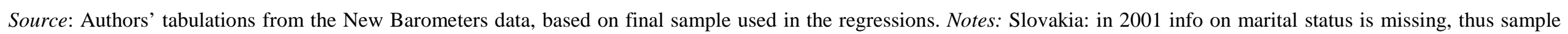

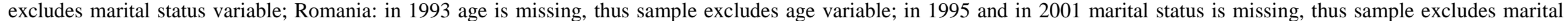

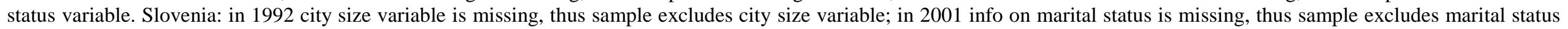
variable. 
Figure 4:

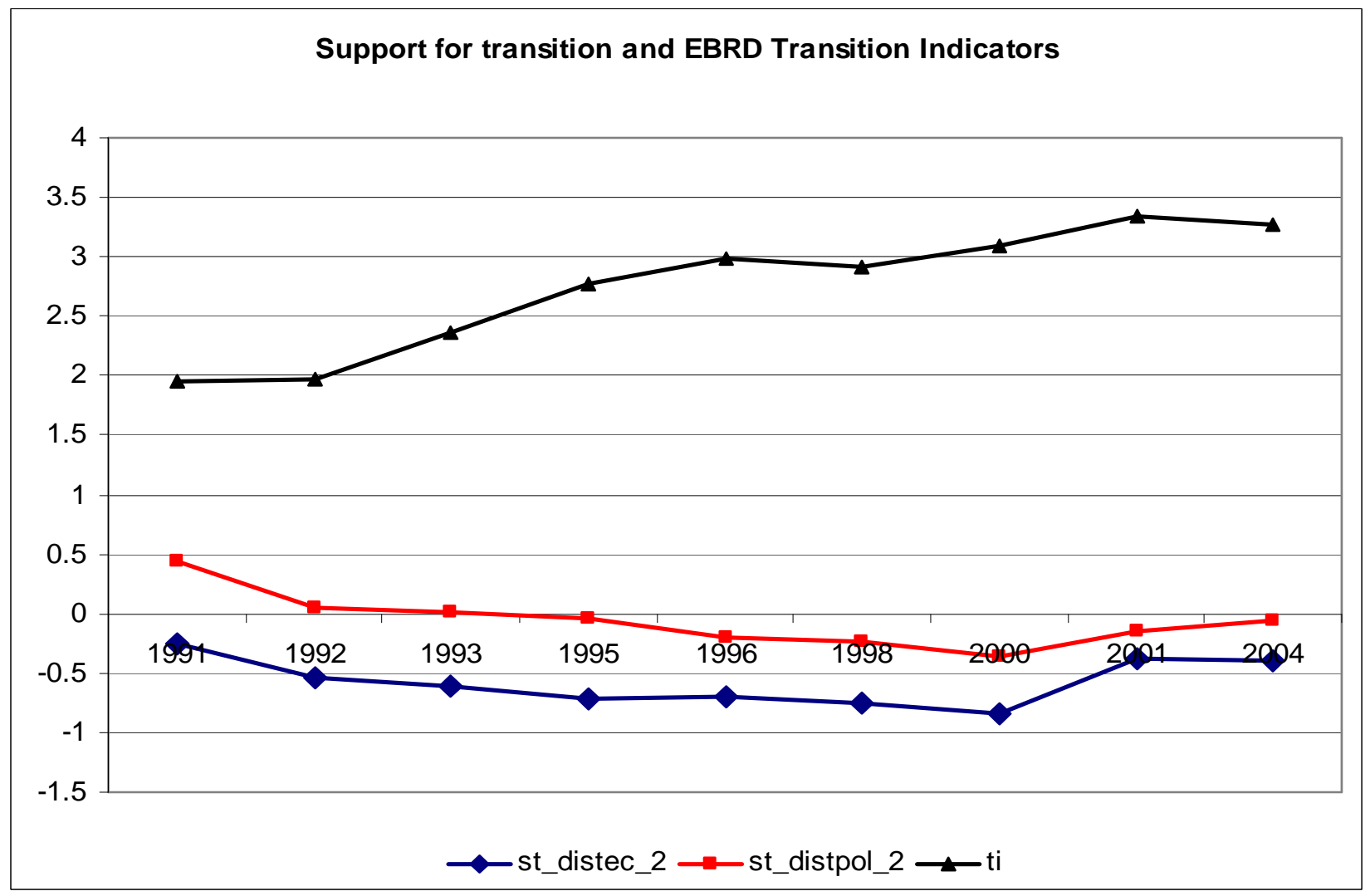

Source: Authors' tabulations from the New Barometers data and EBRD Transition Report (2007). Notes: "ti" stands for the average of EBRD indicators of the progress in transition for countries in the sample in the respective years. 
Table 1: Determinants of individual evaluations of reforms

\begin{tabular}{|c|c|c|c|c|c|c|c|c|}
\hline & (1) & $(2)$ & (3) & (4) & (5) & (6) & (7) & (8) \\
\hline & \multicolumn{4}{|c|}{ Economic system } & \multicolumn{4}{|c|}{ Political system } \\
\hline & $1991-2004$ & 1991-2004 & $1991-98$ & $2000-04$ & $1991-2004$ & $1991-2004$ & $1991-98$ & $2000-04$ \\
\hline \multirow[t]{2}{*}{ Female } & $-0.124 * *$ & $-0.129 * *$ & $-0.140 * *$ & $-0.109 * *$ & $-0.090 * *$ & $-0.090 * *$ & $-0.091 * *$ & $-0.086 * * *$ \\
\hline & $(0.047)$ & $(0.047)$ & $(0.059)$ & $(0.037)$ & $(0.032)$ & $(0.031)$ & $(0.037)$ & $(0.027)$ \\
\hline \multirow[t]{2}{*}{ Young_cohort } & $0.091 * * *$ & $0.080 * * *$ & $0.063 * *$ & $0.107 * * *$ & $0.077 * * *$ & $0.066 * * *$ & 0.045 & $0.097 * * *$ \\
\hline & $(0.019)$ & $(0.023)$ & $(0.028)$ & $(0.028)$ & $(0.017)$ & $(0.018)$ & $(0.027)$ & $(0.031)$ \\
\hline \multirow[t]{2}{*}{ Age 30-39 } & $-0.046^{* *}$ & $-0.042 * *$ & $-0.052 * * *$ & -0.037 & $-0.038 * *$ & $-0.034 * *$ & $-0.060 * * *$ & 0.011 \\
\hline & $(0.016)$ & $(0.017)$ & $(0.016)$ & $(0.033)$ & $(0.013)$ & $(0.014)$ & $(0.016)$ & $(0.036)$ \\
\hline \multirow[t]{2}{*}{ Age $40-49$} & $-0.144 * * *$ & $-0.151 * * *$ & $-0.160 * * *$ & $-0.127 * *$ & $-0.120 * * *$ & $-0.128 * * *$ & $-0.137 * * *$ & $-0.095 * *$ \\
\hline & $(0.024)$ & $(0.024)$ & $(0.024)$ & $(0.047)$ & $(0.017)$ & $(0.018)$ & $(0.020)$ & $(0.038)$ \\
\hline \multirow[t]{2}{*}{ Age 50-59 } & $-0.169 * * *$ & $-0.168 * * *$ & $-0.173 * * *$ & $-0.168 * * *$ & $-0.145 * * *$ & $-0.143 * * *$ & $-0.149 * * *$ & $-0.130 * * *$ \\
\hline & $(0.026)$ & $(0.025)$ & $(0.027)$ & $(0.034)$ & $(0.029)$ & $(0.029)$ & $(0.033)$ & $(0.037)$ \\
\hline \multirow[t]{2}{*}{ Age $>60$} & $-0.106^{*}$ & $-0.111 * *$ & $-0.108 * *$ & $-0.155^{* *}$ & $-0.115^{* *}$ & $-0.112 * *$ & $-0.120 * *$ & $-0.113^{*}$ \\
\hline & $(0.049)$ & $(0.048)$ & $(0.044)$ & $(0.067)$ & $(0.054)$ & $(0.051)$ & $(0.055)$ & $(0.063)$ \\
\hline \multirow{4}{*}{$\begin{array}{l}\text { Secondary / } \\
\text { vocational } \\
\text { University }\end{array}$} & $0.088 * * *$ & $0.063 * *$ & $0.055^{*}$ & $0.104 * *$ & $0.133 * * *$ & $0.117 * * *$ & $0.123 * * *$ & $0.118 * *$ \\
\hline & $(0.029)$ & $(0.028)$ & $(0.029)$ & $(0.042)$ & $(0.027)$ & $(0.025)$ & $(0.024)$ & $(0.045)$ \\
\hline & $0.289 * * *$ & $0.255^{* * *}$ & $0.232 * * *$ & $0.325 * * *$ & $0.335 * * *$ & $0.313 * * *$ & $0.314 * * *$ & $0.321 * * *$ \\
\hline & $(0.026)$ & $(0.028)$ & $(0.035)$ & $(0.036)$ & $(0.029)$ & $(0.023)$ & $(0.028)$ & $(0.038)$ \\
\hline \multirow[t]{2}{*}{ Single } & $0.074 * * *$ & $0.083 * * *$ & $0.055^{* *}$ & $0.125 * * *$ & $0.053 * * *$ & $0.056 * * *$ & 0.030 & $0.113 * * *$ \\
\hline & $(0.022)$ & $(0.018)$ & $(0.025)$ & $(0.025)$ & $(0.017)$ & $(0.016)$ & $(0.023)$ & $(0.019)$ \\
\hline \multirow{4}{*}{$\begin{array}{l}\text { Divorced / } \\
\text { widowed } \\
\text { City }\end{array}$} & 0.026 & $0.036 * *$ & $0.041 * *$ & 0.017 & 0.017 & 0.016 & 0.004 & 0.044 \\
\hline & $(0.018)$ & $(0.014)$ & $(0.018)$ & $(0.022)$ & $(0.022)$ & $(0.018)$ & $(0.020)$ & $(0.034)$ \\
\hline & $0.096^{*}$ & $0.105 * *$ & $0.136 * * *$ & 0.019 & 0.085 & $0.093^{*}$ & $0.111 * *$ & 0.030 \\
\hline & $(0.046)$ & $(0.045)$ & $(0.040)$ & $(0.056)$ & $(0.050)$ & $(0.047)$ & $(0.043)$ & $(0.056)$ \\
\hline \multirow[t]{2}{*}{ Big town } & -0.006 & 0.006 & 0.016 & -0.017 & -0.019 & -0.000 & 0.006 & -0.031 \\
\hline & $(0.024)$ & $(0.023)$ & $(0.028)$ & $(0.027)$ & $(0.032)$ & $(0.030)$ & $(0.035)$ & $(0.040)$ \\
\hline \multirow[t]{2}{*}{ Unemployed } & $-0.149 * * *$ & $-0.138 * * *$ & $-0.140 * * *$ & $-0.155 * * *$ & $-0.112 * * *$ & $-0.099 * * *$ & $-0.113 * * *$ & $-0.096 * * *$ \\
\hline & $(0.034)$ & $(0.028)$ & $(0.039)$ & $(0.032)$ & $(0.025)$ & $(0.023)$ & $(0.030)$ & $(0.028)$ \\
\hline \multirow[t]{2}{*}{ Pensioner } & $-0.054 *$ & -0.048 & $-0.078 * *$ & 0.020 & -0.014 & -0.016 & -0.017 & -0.006 \\
\hline & $(0.031)$ & $(0.029)$ & $(0.033)$ & $(0.031)$ & $(0.025)$ & $(0.023)$ & $(0.024)$ & $(0.043)$ \\
\hline Student / & $0.075 * * *$ & $0.083 * * *$ & $0.098 * * *$ & $0.046^{*}$ & $0.067 * * *$ & $0.074 * * *$ & $0.072 * *$ & $0.066 * * *$ \\
\hline housewife & $(0.015)$ & $(0.015)$ & $(0.019)$ & $(0.022)$ & $(0.020)$ & $(0.020)$ & $(0.030)$ & $(0.020)$ \\
\hline $2^{\text {nd }}$ hh. income & $0.043^{*}$ & $0.054 * * *$ & $0.028 *$ & $0.122 * * *$ & $0.057 * *$ & $0.070 * * *$ & $0.046 * *$ & $0.127 * * *$ \\
\hline quartile & $(0.021)$ & $(0.012)$ & $(0.015)$ & $(0.020)$ & $(0.020)$ & $(0.011)$ & $(0.017)$ & $(0.037)$ \\
\hline $3^{\text {rd }}$ hh. income & $0.135 * * *$ & $0.153 * * *$ & $0.133 * * *$ & $0.204 * * *$ & $0.151 * * *$ & $0.165 * * *$ & $0.155 * * *$ & $0.212 * * *$ \\
\hline quartile & $(0.025)$ & $(0.016)$ & $(0.018)$ & $(0.029)$ & $(0.021)$ & $(0.013)$ & $(0.020)$ & $(0.039)$ \\
\hline $4^{\text {th }}$ hh. income & $0.319 * * *$ & $0.346 * * *$ & $0.291 * * *$ & $0.454 * * *$ & $0.284 * * *$ & $0.302 * * *$ & $0.251 * * *$ & $0.425 * * *$ \\
\hline quartile & $(0.039)$ & $(0.032)$ & $(0.030)$ & $(0.044)$ & $(0.032)$ & $(0.025)$ & $(0.026)$ & $(0.050)$ \\
\hline
\end{tabular}

Cont. 
Cont. Table 1

\begin{tabular}{|c|c|c|c|c|c|c|c|c|}
\hline Czech Republic & $\begin{array}{c}0.522 * * * \\
(0.015)\end{array}$ & & $\begin{array}{c}0.508 * * * \\
(0.023)\end{array}$ & $\begin{array}{c}0.531 * * * \\
(0.010)\end{array}$ & $\begin{array}{c}0.569 * * * \\
(0.025)\end{array}$ & & $\begin{array}{c}0.560 * * * \\
(0.031)\end{array}$ & $\begin{array}{c}0.554 * * * \\
(0.013)\end{array}$ \\
\hline Slovakia & $\begin{array}{c}-0.256 * * * \\
(0.012)\end{array}$ & & $\begin{array}{c}-0.289 * * * \\
(0.015)\end{array}$ & $\begin{array}{c}-0.146 * * * \\
(0.008)\end{array}$ & $\begin{array}{c}-0.081 * * * \\
(0.015)\end{array}$ & & $\begin{array}{c}-0.091 * * * * \\
(0.019)\end{array}$ & $\begin{array}{c}-0.082 * * * \\
(0.008)\end{array}$ \\
\hline Hungary & $\begin{array}{c}-0.387 * * * \\
(0.014)\end{array}$ & & $\begin{array}{c}-0.490 * * * \\
(0.019)\end{array}$ & $\begin{array}{l}-0.035 \\
(0.062)\end{array}$ & $\begin{array}{c}-0.310^{* * * *} \\
(0.016)\end{array}$ & & $\begin{array}{c}-0.407 * * * \\
(0.024)\end{array}$ & $\begin{array}{l}-0.014 \\
(0.055)\end{array}$ \\
\hline Poland & $\begin{array}{c}0.119 * * * \\
(0.012)\end{array}$ & & $\begin{array}{c}0.180 * * * \\
(0.020)\end{array}$ & $\begin{array}{c}0.029 \\
(0.059)\end{array}$ & $\begin{array}{c}0.159 * * * \\
(0.017)\end{array}$ & & $\begin{array}{c}0.207 * * * \\
(0.026)\end{array}$ & $\begin{array}{c}0.059 \\
(0.054)\end{array}$ \\
\hline Estonia & $\begin{array}{l}-0.033 \\
(0.035)\end{array}$ & & $\begin{array}{c}-0.222 * * * \\
(0.057)\end{array}$ & $\begin{array}{c}0.382 * * * \\
(0.079)\end{array}$ & $\begin{array}{c}-0.061 * \\
(0.032)\end{array}$ & & $\begin{array}{c}-0.135 * * * \\
(0.044)\end{array}$ & $\begin{array}{l}0.124 * \\
(0.063)\end{array}$ \\
\hline Lithuania & $\begin{array}{c}-0.677 * * * \\
(0.034)\end{array}$ & & $\begin{array}{c}-0.932 * * * \\
(0.058)\end{array}$ & $\begin{array}{c}-0.213 * * \\
(0.076)\end{array}$ & $\begin{array}{c}-0.300 * * * \\
(0.033)\end{array}$ & & $\begin{array}{c}-0.454 * * * \\
(0.044)\end{array}$ & $\begin{array}{c}-0.022 \\
(0.054)\end{array}$ \\
\hline Latvia & $\begin{array}{c}-0.530 * * * \\
(0.035)\end{array}$ & & $\begin{array}{c}-0.693 * * * \\
(0.057)\end{array}$ & $\begin{array}{l}-0.154^{*} \\
(0.074)\end{array}$ & $\begin{array}{c}-0.323 * * * \\
(0.033)\end{array}$ & & $\begin{array}{c}-0.403 * * * \\
(0.045)\end{array}$ & $\begin{array}{c}-0.121 * * \\
(0.055)\end{array}$ \\
\hline Bulgaria & $\begin{array}{c}-0.370 * * * \\
(0.009)\end{array}$ & & $\begin{array}{c}-0.417 * * * \\
(0.009)\end{array}$ & $\begin{array}{c}-0.148 * * \\
(0.053)\end{array}$ & $\begin{array}{c}-0.069 * * * \\
(0.014)\end{array}$ & & $\begin{array}{l}-0.007 \\
(0.010)\end{array}$ & $\begin{array}{c}-0.083 * \\
(0.044)\end{array}$ \\
\hline Romania & $\begin{array}{c}-0.101 * * * \\
(0.031)\end{array}$ & & $\begin{array}{l}-0.068 \\
(0.041)\end{array}$ & $\begin{array}{c}-0.126^{* * * *} \\
(0.013)\end{array}$ & $\begin{array}{c}0.340 * * * \\
(0.026)\end{array}$ & & $\begin{array}{c}0.411 * * * \\
(0.034)\end{array}$ & $\begin{array}{c}0.114 * * * \\
(0.011)\end{array}$ \\
\hline Croatia & $\begin{array}{c}0.220 * * * \\
(0.036)\end{array}$ & & $\begin{array}{c}0.132 * * * \\
(0.043)\end{array}$ & & $\begin{array}{c}0.266 * * * \\
(0.036)\end{array}$ & & $\begin{array}{c}0.204 * * * \\
(0.046)\end{array}$ & \\
\hline Russia & $\begin{array}{c}-0.688 * * * \\
(0.027)\end{array}$ & & $\begin{array}{c}-0.752 * * * \\
(0.035)\end{array}$ & $\begin{array}{c}-0.438 * * * \\
(0.075)\end{array}$ & $\begin{array}{c}-0.675 * * * \\
(0.021)\end{array}$ & & $\begin{array}{c}-0.788 * * * * \\
(0.028)\end{array}$ & $\begin{array}{c}-0.411 * * * \\
(0.053)\end{array}$ \\
\hline Ukraine & $\begin{array}{c}-1.052 * * * \\
(0.019)\end{array}$ & & $\begin{array}{c}-1.375^{* * *} \\
(0.023)\end{array}$ & $\begin{array}{c}-0.300 * * * \\
(0.016)\end{array}$ & $\begin{array}{c}-0.623 * * * \\
(0.024)\end{array}$ & & $\begin{array}{c}-0.901 * * * \\
(0.026)\end{array}$ & $\begin{array}{c}0.006 \\
(0.016)\end{array}$ \\
\hline Belarus & $\begin{array}{c}-0.749 * * * \\
(0.023)\end{array}$ & & $\begin{array}{c}-1.000 * * * * \\
(0.029)\end{array}$ & $\begin{array}{c}0.098 * * * \\
(0.024)\end{array}$ & $\begin{array}{c}-0.530 * * * \\
(0.026)\end{array}$ & & $\begin{array}{c}-0.712 * * * \\
(0.033)\end{array}$ & $\begin{array}{c}0.095 * * * \\
(0.021)\end{array}$ \\
\hline 1991 & $\begin{array}{l}-0.163 \\
(0.134)\end{array}$ & & $\begin{array}{l}-0.006 \\
(0.101)\end{array}$ & & $\begin{array}{c}0.219 \\
(0.142)\end{array}$ & & $\begin{array}{c}0.210 \\
(0.124)\end{array}$ & \\
\hline 1992 & $\begin{array}{c}-0.366 * * * \\
(0.115)\end{array}$ & & $\begin{array}{c}-0.157 * \\
(0.086)\end{array}$ & & $\begin{array}{l}-0.043 \\
(0.108)\end{array}$ & & $\begin{array}{c}0.022 \\
(0.126)\end{array}$ & \\
\hline 1993 & $\begin{array}{c}-0.288^{* *} \\
(0.125)\end{array}$ & & $\begin{array}{l}-0.010 \\
(0.120)\end{array}$ & & $\begin{array}{c}0.046 \\
(0.108)\end{array}$ & & $\begin{array}{c}0.139 \\
(0.114)\end{array}$ & \\
\hline 1995 & $\begin{array}{c}-0.345 * * \\
(0.152)\end{array}$ & & $\begin{array}{l}-0.076 \\
(0.115)\end{array}$ & & $\begin{array}{c}0.025 \\
(0.134)\end{array}$ & & $\begin{array}{c}0.115 \\
(0.117)\end{array}$ & \\
\hline $\begin{array}{l}1996 \\
1998\end{array}$ & $\begin{array}{c}-0.213 \\
(0.144) \\
-0.248 \\
(0.148)\end{array}$ & & $\begin{array}{c}0.079 \\
(0.120)\end{array}$ & & $\begin{array}{c}0.040 \\
(0.096) \\
-0.086 \\
(0.156)\end{array}$ & & $\begin{array}{c}0.165 \\
(0.102)\end{array}$ & \\
\hline 2000 & $\begin{array}{c}-0.316 * * \\
(0.129)\end{array}$ & & & $\begin{array}{c}-0.357 * * \\
(0.130)\end{array}$ & $\begin{array}{l}-0.087 \\
(0.087)\end{array}$ & & & $\begin{array}{c}-0.144 * * \\
(0.055)\end{array}$ \\
\hline 2001 & $\begin{array}{c}0.041 \\
(0.105)\end{array}$ & & & $\begin{array}{c}0.061 \\
(0.102)\end{array}$ & $\begin{array}{c}-0.001 \\
(0.090)\end{array}$ & & & $\begin{array}{c}0.015 \\
(0.088)\end{array}$ \\
\hline Constant & $\begin{array}{c}-0.093 \\
(0.135)\end{array}$ & $\begin{array}{c}-0.392 * * * \\
(0.054)\end{array}$ & $\begin{array}{c}-0.208 * * \\
(0.095)\end{array}$ & $\begin{array}{c}-0.492 * * * \\
(0.059)\end{array}$ & $\begin{array}{c}0.006 \\
(0.120)\end{array}$ & $\begin{array}{c}-0.195 * * * \\
(0.044)\end{array}$ & $\begin{array}{c}0.001 \\
(0.095)\end{array}$ & $\begin{array}{c}-0.275 * * * \\
(0.066)\end{array}$ \\
\hline $\begin{array}{l}\text { Country*year } \\
\text { dummies }\end{array}$ & No & Yes & No & No & No & Yes & No & No \\
\hline Observations & 72012 & 72012 & 49376 & 22636 & 70532 & 70532 & 48375 & 22157 \\
\hline R-squared & 0.19 & 0.23 & 0.22 & 0.16 & 0.17 & 0.20 & 0.20 & 0.12 \\
\hline
\end{tabular}

Notes: Estimation method: OLS. Standard errors clustered by country are reported in parentheses. * significant at 10 percent; ** significant at 5 percent; *** significant at 1 percent. Dependent variable is the standardized distance between the rankings of present and past economic or political systems. Reference individual is male, age 20-29, cohort between 18 and 55 years old in 1990, less than secondary school education, married, living in rural or small town, employed, with household income in the 1st quartile. Reference country and year: Slovenia, 2004. In columns (3) and (7) reference year is 1998, in columns (4) and (8) reference year is 2004. 
Table 2. Determinants of adhesion to a group, 1991-2004

\begin{tabular}{|c|c|c|c|c|c|c|}
\hline & (1) & (2) & (3) & (4) & (5) & (6) \\
\hline & \multicolumn{3}{|c|}{ Economic system } & \multicolumn{3}{|c|}{ Political system } \\
\hline & Positive & Pro-market & Nostalgic & Compliant & Democrat & Reactionary \\
\hline Female & $\begin{array}{l}-0.015 \\
(0.012)\end{array}$ & $\begin{array}{c}-0.022 * * * \\
(0.007)\end{array}$ & $\begin{array}{c}0.053 * * * \\
(0.020)\end{array}$ & $\begin{array}{c}0.007 \\
(0.005)\end{array}$ & $\begin{array}{c}-0.035 * * * \\
(0.009)\end{array}$ & $\begin{array}{c}0.030 * * \\
(0.013)\end{array}$ \\
\hline \multirow[t]{2}{*}{ Young_cohort } & 0.015 & $0.016 * *$ & $-0.041 * * *$ & 0.010 & $0.019 * *$ & $-0.037 * * *$ \\
\hline & $(0.012)$ & $(0.007)$ & $(0.012)$ & $(0.012)$ & $(0.008)$ & $(0.009)$ \\
\hline \multirow[t]{2}{*}{ Age 30-39 } & -0.003 & $-0.012 * *$ & $0.014 *$ & 0.005 & $-0.014^{*}$ & $0.013 * *$ \\
\hline & $(0.006)$ & $(0.006)$ & $(0.008)$ & $(0.008)$ & $(0.007)$ & $(0.006)$ \\
\hline \multirow[t]{2}{*}{ Age $40-49$} & -0.013 & $-0.030 * * *$ & $0.063 * * *$ & 0.013 & $-0.039 * * *$ & $0.056^{* * *}$ \\
\hline & (0.009) & $(0.005)$ & $(0.008)$ & $(0.012)$ & $(0.009)$ & $(0.009)$ \\
\hline \multirow[t]{2}{*}{ Age 50-59 } & -0.002 & $-0.034 * * *$ & $0.061 * * *$ & $0.019^{*}$ & $-0.045 * * *$ & $0.065 * * *$ \\
\hline & $(0.008)$ & $(0.006)$ & $(0.012)$ & $(0.011)$ & $(0.010)$ & $(0.014)$ \\
\hline \multirow[t]{2}{*}{ Age $>60$} & 0.001 & $-0.019 *$ & 0.038 & 0.008 & $-0.032 *$ & $0.057 * * *$ \\
\hline & $(0.014)$ & $(0.011)$ & $(0.023)$ & $(0.013)$ & $(0.017)$ & $(0.021)$ \\
\hline Secondary / & 0.003 & $0.019 * * *$ & $-0.031 * * *$ & -0.002 & $0.042 * * *$ & $-0.042 * * *$ \\
\hline vocational & $(0.006)$ & $(0.007)$ & $(0.012)$ & $(0.007)$ & $(0.010)$ & $(0.008)$ \\
\hline \multirow{2}{*}{ University } & -0.001 & $0.066^{* * *}$ & $-0.111 * * *$ & $-0.026 * * *$ & $0.114 * * *$ & $-0.104 * * *$ \\
\hline & $(0.010)$ & $(0.008)$ & $(0.013)$ & $(0.007)$ & $(0.011)$ & $(0.009)$ \\
\hline \multirow[t]{2}{*}{ Single } & -0.002 & $0.011 *$ & $-0.029 * * *$ & $-0.013^{*}$ & $0.017 * *$ & $-0.018 * * *$ \\
\hline & $(0.007)$ & $(0.006)$ & $(0.007)$ & $(0.007)$ & $(0.009)$ & $(0.007)$ \\
\hline Divorced / & -0.003 & 0.003 & -0.008 & $-0.012 * *$ & 0.001 & -0.000 \\
\hline widowed & $(0.004)$ & $(0.004)$ & $(0.006)$ & $(0.006)$ & $(0.007)$ & $(0.008)$ \\
\hline \multirow[t]{2}{*}{ City } & -0.011 & $0.025 * *$ & $-0.051 * * *$ & $-0.024^{*}$ & 0.026 & $-0.031 *$ \\
\hline & $(0.010)$ & $(0.011)$ & $(0.016)$ & $(0.014)$ & $(0.020)$ & $(0.016)$ \\
\hline \multirow[t]{2}{*}{ Big town } & 0.002 & 0.004 & -0.010 & -0.005 & -0.001 & -0.001 \\
\hline & $(0.007)$ & $(0.005)$ & $(0.009)$ & $(0.008)$ & $(0.012)$ & $(0.012)$ \\
\hline \multirow[t]{2}{*}{ Unemployed } & -0.006 & $-0.028 * * *$ & $0.048 * * *$ & 0.002 & $-0.039 * * *$ & $0.045^{* * *}$ \\
\hline & $(0.007)$ & $(0.005)$ & $(0.011)$ & $(0.008)$ & $(0.007)$ & $(0.010)$ \\
\hline \multirow[t]{2}{*}{ Pensioner } & 0.009 & $-0.017 * *$ & $0.021 *$ & 0.015 & -0.010 & 0.003 \\
\hline & $(0.010)$ & $(0.007)$ & $(0.012)$ & $(0.010)$ & $(0.010)$ & $(0.010)$ \\
\hline Student / & 0.011 & $0.014 * *$ & $-0.038 * * *$ & $-0.016^{* *}$ & $0.035 * * *$ & $-0.019^{*}$ \\
\hline housewife & $(0.008)$ & $(0.006)$ & $(0.007)$ & $(0.007)$ & (0.009) & $(0.011)$ \\
\hline 2nd hh. income & $0.015 * * *$ & $0.010 * * *$ & $-0.033 * * *$ & 0.005 & $0.021 * * *$ & $-0.024 * * *$ \\
\hline quartile & $(0.004)$ & $(0.004)$ & $(0.006)$ & $(0.004)$ & $(0.005)$ & $(0.003)$ \\
\hline 3rd hh. income & $0.030 * * *$ & $0.029 * * *$ & $-0.069 * * *$ & -0.001 & $0.052 * * *$ & $-0.055 * * *$ \\
\hline quartile & $(0.005)$ & $(0.003)$ & $(0.008)$ & $(0.004)$ & $(0.004)$ & $(0.005)$ \\
\hline 4th hh. income & $0.045^{* * *}$ & $0.078 * * *$ & $-0.152 * * *$ & $-0.013 *$ & $0.106 * * *$ & $-0.103 * * *$ \\
\hline quartile & $(0.006)$ & $(0.0010)$ & $(0.012)$ & $(0.007)$ & $(0.009)$ & $(0.008)$ \\
\hline Observations & 17389 & 9779 & 31271 & 17323 & 18684 & 19674 \\
\hline Observations & & 72012 & & & 70532 & \\
\hline Pseudo R-squared & & 0.12 & & & 0.09 & \\
\hline
\end{tabular}

Notes: Marginal effects from multinomial logit. Standard errors clustered by country are reported in parentheses.

* significant at 10 percent; ** significant at 5 percent; *** significant at 1 percent. Additional regressors include interactions between country and year dummies. Baseline groups are negative and skeptic, for economic and political outcomes, respectively. 
Table 3. The impact of additional variables on individual evaluations

\begin{tabular}{|c|c|c|c|c|c|c|c|c|c|c|c|c|}
\hline & (1) & (2) & (3) & (4) & (5) & (6) & (7) & (8) & (9) & (10) & (11) & (12) \\
\hline & $\begin{array}{l}\text { Nr. weeks } \\
\text { hardship }\end{array}$ & $\begin{array}{c}\text { Doing } \\
\text { without }\end{array}$ & $\begin{array}{l}\text { Ref. fast }+ \\
\text { Ref. slow }\end{array}$ & $\begin{array}{l}\text { Parliament } \\
\text { suspend }\end{array}$ & Leader & Corruption & $\begin{array}{l}\text { Equal } \\
\text { income }\end{array}$ & $\begin{array}{c}\text { Ex- } \\
\text { communist }\end{array}$ & Trust parties & $\begin{array}{c}\text { Trust } \\
\text { Parliament }\end{array}$ & $\begin{array}{c}\text { Trust } \\
\text { president }\end{array}$ & Trust people \\
\hline $\begin{array}{c}\text { Dependent } \\
\text { variable: }\end{array}$ & \multicolumn{12}{|c|}{ Support for change in the economic system } \\
\hline & $\begin{array}{c}-0.003 * * * \\
(0.001)\end{array}$ & $\begin{array}{c}-0.061 * * * \\
(0.006)\end{array}$ & $\begin{array}{c}-0.496 * * * \\
(0.050) \\
-0.280 * * * \\
(0.047)\end{array}$ & $\begin{array}{c}-0.301 * * * \\
(0.036)\end{array}$ & $\begin{array}{c}-0.287 * * * \\
(0.024)\end{array}$ & $\begin{array}{c}-0.313 * * * \\
(0.032)\end{array}$ & $\begin{array}{c}-0.218 * * * \\
(0.025)\end{array}$ & $\begin{array}{c}-0.210 * * * \\
(0.027)\end{array}$ & $\begin{array}{c}0.081 * * * \\
(0.016)\end{array}$ & $\begin{array}{c}0.084 * * * \\
(0.014)\end{array}$ & $\begin{array}{c}0.082 * * * \\
(0.013)\end{array}$ & $\begin{array}{l}0.023 * \\
(0.011)\end{array}$ \\
\hline $\begin{array}{l}\text { Observations } \\
\text { R-squared }\end{array}$ & $\begin{array}{c}27834 \\
0.27\end{array}$ & $\begin{array}{c}33608 \\
0.28\end{array}$ & $\begin{array}{c}14392 \\
0.31\end{array}$ & $\begin{array}{c}60607 \\
0.24\end{array}$ & $\begin{array}{c}59298 \\
0.25\end{array}$ & $\begin{array}{c}16040 \\
0.15\end{array}$ & $\begin{array}{c}37363 \\
0.24\end{array}$ & $\begin{array}{c}18271 \\
0.33\end{array}$ & $\begin{array}{c}53698 \\
0.24\end{array}$ & $\begin{array}{c}54279 \\
0.24\end{array}$ & $\begin{array}{c}51135 \\
0.25\end{array}$ & $\begin{array}{c}25092 \\
0.19\end{array}$ \\
\hline $\begin{array}{c}\text { Dependent } \\
\text { variable: }\end{array}$ & \multicolumn{12}{|c|}{ Support for change in the political system } \\
\hline & $\begin{array}{c}-0.003 * * * \\
(0.001)\end{array}$ & $\begin{array}{c}-0.049 * * * \\
(0.006)\end{array}$ & $\begin{array}{c}-0.443 * * * \\
(0.037) \\
-0.168 * * * \\
(0.045)\end{array}$ & $\begin{array}{c}-0.383 * * * \\
(0.060)\end{array}$ & $\begin{array}{c}-0.376 * * * \\
(0.023)\end{array}$ & $\begin{array}{c}-0.333 * * * \\
(0.036)\end{array}$ & $\begin{array}{c}-0.288 * * * \\
(0.024)\end{array}$ & $\begin{array}{c}-0.251 * * * \\
(0.034)\end{array}$ & $\begin{array}{c}0.093 * * * \\
(0.019)\end{array}$ & $\begin{array}{c}0.095 * * * \\
(0.018)\end{array}$ & $\begin{array}{c}0.102 * * * \\
(0.018)\end{array}$ & $\begin{array}{c}0.032 * * * \\
(0.010)\end{array}$ \\
\hline $\begin{array}{c}\text { Observations } \\
\text { R-squared }\end{array}$ & $\begin{array}{c}27219 \\
0.22\end{array}$ & $\begin{array}{c}33011 \\
0.24\end{array}$ & $\begin{array}{c}14131 \\
0.24\end{array}$ & $\begin{array}{c}59771 \\
0.22\end{array}$ & $\begin{array}{c}58238 \\
0.21\end{array}$ & $\begin{array}{c}15730 \\
0.12\end{array}$ & $\begin{array}{c}36543 \\
0.20\end{array}$ & $\begin{array}{c}18147 \\
0.27\end{array}$ & $\begin{array}{c}52854 \\
0.20\end{array}$ & $\begin{array}{c}53390 \\
0.21\end{array}$ & $\begin{array}{c}50274 \\
0.21\end{array}$ & $\begin{array}{c}24741 \\
0.16\end{array}$ \\
\hline
\end{tabular}

Notes: Estimation method: OLS. Standard errors clustered by country are in parentheses. * significant at 10 percent; ** significant at 5 percent; *** significant at 1 percent.

For definitions of the variables, see text and Data Appendix. Additional controls include country and year dummies interactions. 
Table 4. Role of individual preferences in explaining the lower evaluation of economic reforms in the CIS

\begin{tabular}{|c|c|c|c|c|c|c|c|c|c|c|c|c|c|c|}
\hline & $\begin{array}{c}\text { (1) } \\
\text { Trustpart }\end{array}$ & $\begin{array}{c}(2) \\
\text { Trustpart }\end{array}$ & $\begin{array}{c}(3) \\
\text { Trustparl }\end{array}$ & $\begin{array}{c}(4) \\
\text { Trustparl }\end{array}$ & $\begin{array}{c}(5) \\
\text { Trustpres }\end{array}$ & $\begin{array}{c}(6) \\
\text { Trustpres }\end{array}$ & $\begin{array}{c}\text { (7) } \\
\text { Equalinc }\end{array}$ & $\begin{array}{c}\text { (8) } \\
\text { Equalinc }\end{array}$ & $\begin{array}{c}(9) \\
\text { Stateresp }\end{array}$ & $\begin{array}{c}(10) \\
\text { Stateresp }\end{array}$ & $\begin{array}{c}(11) \\
\text { Stateprop }\end{array}$ & $\begin{array}{c}(12) \\
\text { Stateprop }\end{array}$ & $\begin{array}{c}(13) \\
\text { Securejob }\end{array}$ & $\begin{array}{c}(14) \\
\text { Securejob }\end{array}$ \\
\hline Belarus & $\begin{array}{c}-0.822 * * * \\
(0.019)\end{array}$ & $\begin{array}{c}-0.818^{* * *} \\
(0.019)\end{array}$ & $\begin{array}{c}-0.827 * * * \\
(0.019)\end{array}$ & $\begin{array}{c}-0.839 * * * \\
(0.017)\end{array}$ & $\begin{array}{c}-0.831 * * * \\
(0.020)\end{array}$ & $\begin{array}{c}-0.815^{* * *} \\
(0.019)\end{array}$ & $\begin{array}{c}-0.606^{* * *} \\
(0.024)\end{array}$ & $\begin{array}{c}-0.623 * * * \\
(0.023)\end{array}$ & $\begin{array}{c}-0.613 * * * \\
(0.024)\end{array}$ & $\begin{array}{c}-0.609 * * * \\
(0.024)\end{array}$ & $\begin{array}{c}-0.621 * * * \\
(0.023)\end{array}$ & $\begin{array}{c}-0.521 * * * \\
(0.019)\end{array}$ & $\begin{array}{c}-0.551 * * * \\
(0.009)\end{array}$ & $\begin{array}{c}-0.582 * * * \\
(0.010)\end{array}$ \\
\hline Ukraine & $\begin{array}{c}-1.095^{* * *} \\
(0.013)\end{array}$ & $\begin{array}{c}-1.076 * * * \\
(0.014)\end{array}$ & $\begin{array}{c}-1.095^{* * *} \\
(0.013)\end{array}$ & $\begin{array}{c}-1.046 * * * \\
(0.016)\end{array}$ & $\begin{array}{c}-1.104 * * * \\
(0.013)\end{array}$ & $\begin{array}{c}-1.016^{* * *} \\
(0.020)\end{array}$ & $\begin{array}{c}-1.004 * * * \\
(0.019)\end{array}$ & $\begin{array}{c}-1.007 * * * \\
(0.019)\end{array}$ & $\begin{array}{c}-1.007 * * * \\
(0.018)\end{array}$ & $\begin{array}{c}-0.986 * * * \\
(0.018)\end{array}$ & $\begin{array}{c}-1.019 * * * \\
(0.017)\end{array}$ & $\begin{array}{c}-0.910 * * * \\
(0.024)\end{array}$ & $\begin{array}{c}-0.788 * * * \\
(0.032)\end{array}$ & $\begin{array}{c}-0.806^{* * * *} \\
(0.032)\end{array}$ \\
\hline Russia & $\begin{array}{c}-0.697 * * * \\
(0.047)\end{array}$ & $\begin{array}{c}-0.646^{* * *} \\
(0.049)\end{array}$ & $\begin{array}{c}-0.708^{* * *} \\
(0.046)\end{array}$ & $\begin{array}{c}-0.628 * * * \\
(0.048)\end{array}$ & $\begin{array}{c}-0.709 * * * \\
(0.047)\end{array}$ & $\begin{array}{c}-0.620 * * * \\
(0.053)\end{array}$ & $\begin{array}{c}-0.549 * * * \\
(0.088)\end{array}$ & $\begin{array}{c}-0.532 * * * \\
(0.091)\end{array}$ & $\begin{array}{c}-0.554 * * * \\
(0.088)\end{array}$ & $\begin{array}{c}-0.560 * * * \\
(0.082)\end{array}$ & $\begin{array}{c}-0.574 * * * \\
(0.089)\end{array}$ & $\begin{array}{c}-0.451 * * * \\
(0.091)\end{array}$ & $\begin{array}{c}-0.546 * * * \\
(0.080)\end{array}$ & $\begin{array}{c}-0.592 * * * \\
(0.082)\end{array}$ \\
\hline Trustpart & & $\begin{array}{c}0.092 * * * \\
(0.018)\end{array}$ & & & & & & & & & & & & \\
\hline Trustparl & & & & $\begin{array}{c}0.100 * * * \\
(0.015)\end{array}$ & & & & & & & & & & \\
\hline Trustpres & & & & & & $\begin{array}{c}0.086^{* * *} \\
(0.011)\end{array}$ & & & & & & & & \\
\hline Equalinc & & & & & & & & $\begin{array}{c}-0.228 * * * \\
(0.027)\end{array}$ & & & & & & \\
\hline Stateresp & & & & & & & & & & $\begin{array}{c}-0.306 * * * \\
(0.027)\end{array}$ & & & & \\
\hline Stateprop & & & & & & & & & & & & $\begin{array}{c}-0.384 * * * \\
(0.030)\end{array}$ & & \\
\hline Securejob & & & & & & & & & & & & & & $\begin{array}{c}-0.193 * * * \\
(0.033)\end{array}$ \\
\hline Constant & $\begin{array}{l}-0.094 \\
(0.138)\end{array}$ & $\begin{array}{c}-0.347 * * \\
(0.136)\end{array}$ & $\begin{array}{l}-0.085 \\
(0.137)\end{array}$ & $\begin{array}{c}-0.415 * * * \\
(0.123)\end{array}$ & $\begin{array}{l}-0.072 \\
(0.138)\end{array}$ & $\begin{array}{c}-0.497 * * * \\
(0.141)\end{array}$ & $\begin{array}{l}-0.197 \\
(0.157)\end{array}$ & $\begin{array}{l}-0.092 \\
(0.152)\end{array}$ & $\begin{array}{l}-0.199 \\
(0.155)\end{array}$ & $\begin{array}{l}-0.023 \\
(0.143)\end{array}$ & $\begin{array}{l}-0.198 \\
(0.158)\end{array}$ & $\begin{array}{l}-0.042 \\
(0.143)\end{array}$ & $\begin{array}{l}-0.200 \\
(0.128)\end{array}$ & $\begin{array}{l}-0.071 \\
(0.124)\end{array}$ \\
\hline Observations & 53698 & 53698 & 54279 & 54279 & 51135 & 51135 & 37363 & 37363 & 37261 & 37261 & 36164 & 36164 & 26921 & 26921 \\
\hline R-squared & 0.19 & 0.21 & 0.19 & 0.21 & 0.19 & 0.21 & 0.19 & 0.19 & 0.19 & 0.20 & 0.19 & 0.21 & 0.16 & 0.16 \\
\hline
\end{tabular}

Notes: Estimation method: OLS. Standard errors clustered by country are in parentheses. * significant at 10 percent; ** significant at 5 percent; *** significant at 1 percent. Additional controls include individual characteristics as in Table 1, country fixed effects and year dummies. 
Table 5. Role of individual preferences in explaining the lower evaluation of political reforms in the CIS

\begin{tabular}{|c|c|c|c|c|c|c|c|c|c|c|c|c|c|c|}
\hline & $\begin{array}{c}\text { (1) } \\
\text { Trustpart }\end{array}$ & $\begin{array}{c}\text { (2) } \\
\text { Trustpart }\end{array}$ & $\begin{array}{c}(3) \\
\text { Trustparl }\end{array}$ & $\begin{array}{c}\text { (4) } \\
\text { Trustparl }\end{array}$ & $\begin{array}{c}\text { (5) } \\
\text { Trustpres }\end{array}$ & $\begin{array}{c}\text { (6) } \\
\text { Trustpres }\end{array}$ & $\begin{array}{c}(7) \\
\text { Equalinc }\end{array}$ & $\begin{array}{c}\text { (8) } \\
\text { Equalinc }\end{array}$ & $\begin{array}{c}(9) \\
\text { Stateresp }\end{array}$ & $\begin{array}{c}(10) \\
\text { Stateresp }\end{array}$ & $\begin{array}{c}\text { (11) } \\
\text { Stateprop }\end{array}$ & $\begin{array}{c}\text { (12) } \\
\text { Stateprop }\end{array}$ & $\begin{array}{c}(13) \\
\text { Securejob }\end{array}$ & $\begin{array}{c}\text { (14) } \\
\text { Securejob }\end{array}$ \\
\hline Belarus & $\begin{array}{c}-0.586^{* * * *} \\
(0.020)\end{array}$ & $\begin{array}{c}-0.581 * * * \\
(0.019)\end{array}$ & $\begin{array}{c}-0.592 * * * \\
(0.020)\end{array}$ & $\begin{array}{c}-0.604 * * * \\
(0.017)\end{array}$ & $\begin{array}{c}-0.595 * * * \\
(0.021)\end{array}$ & $\begin{array}{c}-0.573 * * * \\
(0.019)\end{array}$ & $\begin{array}{c}-0.403 * * * \\
(0.025)\end{array}$ & $\begin{array}{c}-0.423 * * * \\
(0.024)\end{array}$ & $\begin{array}{c}-0.409 * * * \\
(0.025)\end{array}$ & $\begin{array}{c}-0.408 * * * \\
(0.025)\end{array}$ & $\begin{array}{c}-0.415 * * * \\
(0.024)\end{array}$ & $\begin{array}{c}-0.297 * * * \\
(0.022)\end{array}$ & $\begin{array}{c}-0.416 * * * \\
(0.008)\end{array}$ & $\begin{array}{c}-0.449 * * * \\
(0.010)\end{array}$ \\
\hline Ukraine & $\begin{array}{c}-0.715 * * * \\
(0.011)\end{array}$ & $\begin{array}{c}-0.695^{* * *} \\
(0.013)\end{array}$ & $\begin{array}{c}-0.715^{* * *} \\
(0.012)\end{array}$ & $\begin{array}{c}-0.660 * * * \\
(0.017)\end{array}$ & $\begin{array}{c}-0.717 * * * \\
(0.012)\end{array}$ & $\begin{array}{c}-0.606^{* * *} \\
(0.020)\end{array}$ & $\begin{array}{c}-0.586 * * * \\
(0.024)\end{array}$ & $\begin{array}{c}-0.589 * * * \\
(0.026)\end{array}$ & $\begin{array}{c}-0.593 * * * \\
(0.024)\end{array}$ & $\begin{array}{c}-0.576 * * * \\
(0.024)\end{array}$ & $\begin{array}{c}-0.613 * * * \\
(0.023)\end{array}$ & $\begin{array}{c}-0.487 * * * \\
(0.028)\end{array}$ & $\begin{array}{c}-0.391 * * * \\
(0.028)\end{array}$ & $\begin{array}{c}-0.408 * * * \\
(0.028)\end{array}$ \\
\hline Russia & $\begin{array}{c}-0.653 * * * \\
(0.032)\end{array}$ & $\begin{array}{c}-0.596^{* * * *} \\
(0.032)\end{array}$ & $\begin{array}{c}-0.663 * * * \\
(0.032)\end{array}$ & $\begin{array}{c}-0.574 * * * \\
(0.032)\end{array}$ & $\begin{array}{c}-0.662 * * * \\
(0.032)\end{array}$ & $\begin{array}{c}-0.550 * * * \\
(0.038)\end{array}$ & $\begin{array}{c}-0.624 * * * \\
(0.089)\end{array}$ & $\begin{array}{c}-0.602 * * * \\
(0.091)\end{array}$ & $\begin{array}{c}-0.632 * * * \\
(0.090)\end{array}$ & $\begin{array}{c}-0.638 * * * \\
(0.087)\end{array}$ & $\begin{array}{c}-0.642 * * * \\
(0.089)\end{array}$ & $\begin{array}{c}-0.495 * * * \\
(0.093)\end{array}$ & $\begin{array}{c}-0.609 * * * \\
(0.058)\end{array}$ & $\begin{array}{c}-0.655^{* * *} \\
(0.062)\end{array}$ \\
\hline Trustpart & & $\begin{array}{c}0.102 * * * \\
(0.020)\end{array}$ & & & & & & & & & & & & \\
\hline Trustparl & & & & $\begin{array}{c}0.109 * * * \\
(0.019)\end{array}$ & & & & & & & & & & \\
\hline Trustpres & & & & & & $\begin{array}{c}0.107 * * * \\
(0.016)\end{array}$ & & & & & & & & \\
\hline Equalinc & & & & & & & & $\begin{array}{c}-0.285 * * * \\
(0.024)\end{array}$ & & & & & & \\
\hline Stateresp & & & & & & & & & & $\begin{array}{c}-0.266 * * * \\
(0.034)\end{array}$ & & & & \\
\hline Stateprop & & & & & & & & & & & & $\begin{array}{c}-0.456 * * * \\
(0.031)\end{array}$ & & \\
\hline Securejob & & & & & & & & & & & & & & $\begin{array}{c}-0.202 * * * \\
(0.033)\end{array}$ \\
\hline Constant & $\begin{array}{c}0.001 \\
(0.121)\end{array}$ & $\begin{array}{c}-0.277 * * \\
(0.125)\end{array}$ & $\begin{array}{c}0.010 \\
(0.121)\end{array}$ & $\begin{array}{c}-0.350 * * * \\
(0.109)\end{array}$ & $\begin{array}{c}0.034 \\
(0.119)\end{array}$ & $\begin{array}{c}-0.502 * * * \\
(0.127)\end{array}$ & $\begin{array}{l}-0.051 \\
(0.156)\end{array}$ & $\begin{array}{c}0.079 \\
(0.153)\end{array}$ & $\begin{array}{l}-0.049 \\
(0.156)\end{array}$ & $\begin{array}{c}0.107 \\
(0.146)\end{array}$ & $\begin{array}{l}-0.055 \\
(0.154)\end{array}$ & $\begin{array}{c}0.131 \\
(0.141)\end{array}$ & $\begin{array}{l}-0.073 \\
(0.105)\end{array}$ & $\begin{array}{c}0.062 \\
(0.110)\end{array}$ \\
\hline Observations & 52854 & 52854 & 53390 & 53390 & 50274 & 50274 & 36543 & 36543 & 36433 & 36433 & 35442 & 35442 & 26207 & 26207 \\
\hline R-squared & 0.16 & 0.18 & 0.16 & 0.18 & 0.15 & 0.19 & 0.15 & 0.16 & 0.15 & 0.16 & 0.15 & 0.19 & 0.12 & 0.13 \\
\hline
\end{tabular}

Notes: Estimation method: OLS. Standard errors clustered by country are in parentheses. * significant at 10 percent; ** significant at 5 percent; *** significant at 1 percent. Additional controls include individual characteristics as in Table 1, country fixed effects and year dummies. 
Table 6: Role of macroeconomic and institutional determinants in explaining the lower evaluation of economic reforms in the CIS

\begin{tabular}{|c|c|c|c|c|c|c|c|}
\hline & (1) & (2) & (3) & (4) & (5) & (6) & (7) \\
\hline Belarus & $\begin{array}{c}-0.749 * * * \\
(0.023)\end{array}$ & $\begin{array}{c}-1.519 * * \\
(0.519)\end{array}$ & $\begin{array}{c}-1.347 * * \\
(0.481)\end{array}$ & $\begin{array}{c}-3.064 * * \\
(1.024)\end{array}$ & $\begin{array}{c}-3.196 * * * \\
(0.877)\end{array}$ & $\begin{array}{c}-3.146 * \\
(1.565)\end{array}$ & $\begin{array}{c}0.197 \\
(1.368)\end{array}$ \\
\hline Ukraine & $\begin{array}{c}-1.052 * * * \\
(0.019)\end{array}$ & $\begin{array}{c}-1.412 * * * \\
(0.460)\end{array}$ & $\begin{array}{c}-1.288 * * * \\
(0.421)\end{array}$ & $\begin{array}{c}-2.351 * * \\
(0.778)\end{array}$ & $\begin{array}{c}-2.059 * * \\
(0.729)\end{array}$ & $\begin{array}{c}-2.600 * * \\
(1.146)\end{array}$ & $\begin{array}{c}0.137 \\
(1.125)\end{array}$ \\
\hline Russia & $\begin{array}{c}-0.688 * * * \\
(0.027)\end{array}$ & $\begin{array}{c}-1.086 * * \\
(0.362)\end{array}$ & $\begin{array}{c}-1.024 * * * \\
(0.333)\end{array}$ & $\begin{array}{c}-1.984 * * * \\
(0.635)\end{array}$ & $\begin{array}{c}-1.377 * \\
(0.669)\end{array}$ & $\begin{array}{c}-2.133 * * \\
(0.926)\end{array}$ & $\begin{array}{c}1.399 \\
(1.089)\end{array}$ \\
\hline Unempl. Rate & & $\begin{array}{l}-0.013 \\
(0.007)\end{array}$ & $\begin{array}{c}-0.017 * * \\
(0.006)\end{array}$ & $\begin{array}{c}-0.040 * * \\
(0.017)\end{array}$ & $\begin{array}{c}-0.044 * * * \\
(0.014)\end{array}$ & $\begin{array}{l}-0.047 \\
(0.030)\end{array}$ & $\begin{array}{c}0.005 \\
(0.019)\end{array}$ \\
\hline GDP p.c. & & $\begin{array}{l}-0.001 \\
(0.039)\end{array}$ & $\begin{array}{l}-0.003 \\
(0.035)\end{array}$ & $\begin{array}{l}-0.071 \\
(0.056)\end{array}$ & $\begin{array}{l}-0.077 \\
(0.052)\end{array}$ & $\begin{array}{l}-0.109 \\
(0.084)\end{array}$ & $\begin{array}{l}-0.138 * \\
(0.071)\end{array}$ \\
\hline Inflation & & $\begin{array}{l}-0.000 \\
(0.000)\end{array}$ & $\begin{array}{l}-0.000 \\
(0.000)\end{array}$ & $\begin{array}{c}0.000 \\
(0.000)\end{array}$ & $\begin{array}{c}0.000 \\
(0.000)\end{array}$ & $\begin{array}{l}-0.001 \\
(0.000)\end{array}$ & $\begin{array}{c}-0.002 * * \\
(0.001)\end{array}$ \\
\hline Democracy & & $\begin{array}{c}-0.092 * * * \\
(0.019)\end{array}$ & $\begin{array}{c}-0.096 * * * \\
(0.021)\end{array}$ & $\begin{array}{c}-0.157 * * * \\
(0.050)\end{array}$ & $\begin{array}{c}-0.151 * * * \\
(0.048)\end{array}$ & $\begin{array}{l}-0.136 \\
(0.077)\end{array}$ & $\begin{array}{c}-0.111^{* *} \\
(0.045)\end{array}$ \\
\hline Tr. Indic.(t-1) & & & $\begin{array}{l}0.185 * \\
(0.099)\end{array}$ & & & & \\
\hline Gini & & & & & $\begin{array}{c}-3.785 * * * \\
(0.994)\end{array}$ & & \\
\hline Gov. Indic. & & & & & & & \\
\hline Voice & & & & & & & $\begin{array}{c}-0.014 * * \\
(0.006)\end{array}$ \\
\hline Pol. Stab. & & & & & & & $\begin{array}{c}0.038 * * * \\
(0.007)\end{array}$ \\
\hline Gov. effect. & & & & & & & $\begin{array}{l}-0.010 \\
(0.007)\end{array}$ \\
\hline Regul. qual. & & & & & & & $\begin{array}{l}0.012 * \\
(0.006)\end{array}$ \\
\hline Rule of law & & & & & & & $\begin{array}{c}0.032 * * * \\
(0.007)\end{array}$ \\
\hline Control corr. & & & & & & & $\begin{array}{l}-0.000 \\
(0.008)\end{array}$ \\
\hline Constant & $\begin{array}{l}-0.093 \\
(0.135)\end{array}$ & $\begin{array}{c}0.991 \\
(0.874)\end{array}$ & $\begin{array}{c}0.445 \\
(0.836)\end{array}$ & $\begin{array}{l}3.008 * \\
(1.541)\end{array}$ & $\begin{array}{c}4.088 * * * \\
(1.150)\end{array}$ & $\begin{array}{c}3.529 \\
(2.192)\end{array}$ & $\begin{array}{l}-1.304 \\
(1.901)\end{array}$ \\
\hline Observations & 72012 & 72012 & 72012 & 48967 & 48967 & 40420 & 40420 \\
\hline R-squared & 0.19 & 0.20 & 0.20 & 0.19 & 0.20 & 0.21 & 0.23 \\
\hline
\end{tabular}

Notes: Estimation method: OLS. Standard errors clustered by country are in parentheses. * significant at 10 percent; $* *$ significant at 5 percent; *** significant at 1 percent. For definitions of macro and institutional variables, see text and Data Appendix. Additional controls include individual characteristics as in Table 1 and year dummies. 
Table 7: Role of macroeconomic and institutional determinants in explaining the lower evaluation of political reforms in the CIS

\begin{tabular}{|c|c|c|c|c|c|c|c|}
\hline & (1) & (2) & (3) & (4) & $(5)$ & (6) & $(7)$ \\
\hline \multirow[t]{2}{*}{ Belarus } & $-0.530 * * *$ & $-0.962 *$ & $-0.937 *$ & -1.697 & -1.799 & -2.119 & -1.063 \\
\hline & $(0.026)$ & $(0.483)$ & $(0.457)$ & (1.175) & (1.044) & (2.066) & (1.336) \\
\hline \multirow[t]{2}{*}{ Ukraine } & $-0.623 * * *$ & -0.678 & -0.660 & -1.149 & -0.960 & -1.755 & -0.991 \\
\hline & $(0.024)$ & $(0.453)$ & $(0.437)$ & $(0.895)$ & $(0.848)$ & (1.453) & (1.099) \\
\hline \multirow[t]{2}{*}{ Russia } & $-0.675 * * *$ & $-0.851 * *$ & $-0.842 * *$ & -1.267 & -0.864 & -1.639 & -0.063 \\
\hline & $(0.021)$ & $(0.337)$ & $(0.327)$ & $(0.715)$ & $(0.731)$ & (1.173) & $(0.973)$ \\
\hline \multirow[t]{2}{*}{ Unempl. Rate } & & -0.011 & -0.011 & $-0.027 *$ & $-0.030 * *$ & -0.040 & -0.017 \\
\hline & & $(0.008)$ & $(0.008)$ & $(0.015)$ & $(0.013)$ & $(0.029)$ & $(0.026)$ \\
\hline \multirow[t]{2}{*}{ GDP p.c. } & & 0.018 & 0.018 & -0.016 & -0.020 & -0.084 & $-0.176^{*}$ \\
\hline & & $(0.037)$ & $(0.037)$ & $(0.065)$ & $(0.060)$ & $(0.101)$ & $(0.082)$ \\
\hline \multirow[t]{2}{*}{ Inflation } & & $-0.000 *$ & $-0.000 *$ & $-0.000 * *$ & -0.000 & -0.001 & $-0.001 * *$ \\
\hline & & $(0.000)$ & $(0.000)$ & $(0.000)$ & $(0.000)$ & $(0.001)$ & $(0.001)$ \\
\hline \multirow[t]{2}{*}{ Democracy } & & $-0.080 * * *$ & $-0.081 * * *$ & $-0.118 *$ & $-0.114 * *$ & -0.085 & -0.083 \\
\hline & & $(0.024)$ & $(0.026)$ & $(0.056)$ & $(0.051)$ & $(0.103)$ & $(0.049)$ \\
\hline \multirow[t]{2}{*}{ Tr. Indic. (t-1) } & & & 0.027 & & & & \\
\hline & & & $(0.106)$ & & & & \\
\hline \multirow[t]{2}{*}{ Gini } & & & & & $-2.570 * * *$ & & \\
\hline & & & & & $(0.773)$ & & \\
\hline \multicolumn{8}{|l|}{ Gov. Indic. } \\
\hline \multirow[t]{2}{*}{ Voice } & & & & & & & $-0.016 * *$ \\
\hline & & & & & & & $(0.006)$ \\
\hline \multirow[t]{2}{*}{ Pol. Stab. } & & & & & & & $0.021 * *$ \\
\hline & & & & & & & $(0.007)$ \\
\hline \multirow[t]{2}{*}{ Gov. Effect. } & & & & & & & -0.005 \\
\hline & & & & & & & $(0.007)$ \\
\hline \multirow[t]{2}{*}{ Regul. Qual. } & & & & & & & 0.004 \\
\hline & & & & & & & $(0.005)$ \\
\hline \multirow[t]{2}{*}{ Rule of law } & & & & & & & $0.045^{* * *}$ \\
\hline & & & & & & & $(0.009)$ \\
\hline \multirow[t]{2}{*}{ Control corr. } & & & & & & & -0.012 \\
\hline & & & & & & & $(0.007)$ \\
\hline \multirow[t]{2}{*}{ Constant } & -0.006 & 0.590 & 0.510 & 1.602 & 2.353 & 2.652 & 1.218 \\
\hline & $(0.120)$ & $(0.847)$ & $(0.793)$ & $(1.777)$ & $(1.453)$ & $(2.838)$ & $(1.968)$ \\
\hline Observations & 70532 & 70532 & 70532 & 48165 & 48165 & 39666 & 39666 \\
\hline R-squared & 0.17 & 0.17 & 0.17 & 0.18 & 0.18 & 0.16 & 0.17 \\
\hline
\end{tabular}

Notes: Estimation method: OLS. Standard errors clustered by country are in parentheses. * significant at 10 percent; ** significant at 5 percent; *** significant at 1 percent. For definitions of macro and institutional variables, see text and Data Appendix. Additional controls include individual characteristics as in Table 1 and year dummies. 
Table 8: Robustness checks

\begin{tabular}{|c|c|c|c|c|c|}
\hline & (1) & (2) & (3) & (4) & $(5)$ \\
\hline $\begin{array}{l}\text { Dependent } \\
\text { variable: }\end{array}$ & Distance_Econ. & Distance_Pol. & Higher_Econ. & Higher_Pol. & $\begin{array}{c}\text { Return to } \\
\text { Communism }\end{array}$ \\
\hline $\begin{array}{l}\text { Estimation } \\
\text { method }\end{array}$ & OLS & OLS & Probit & Probit & Probit \\
\hline Female & $\begin{array}{c}-9.003 * * \\
(3.395)\end{array}$ & $\begin{array}{c}-7.367 * * \\
(2.584)\end{array}$ & $\begin{array}{c}-0.042 * * * \\
(0.013)\end{array}$ & $\begin{array}{c}-0.050 * * * \\
(0.013)\end{array}$ & $\begin{array}{c}0.019 * * * \\
(0.007)\end{array}$ \\
\hline Young_Cohort & $\begin{array}{c}7.292 * * * \\
(1.336)\end{array}$ & $\begin{array}{c}6.109 * * * \\
(1.297)\end{array}$ & $\begin{array}{c}0.035 * * * \\
(0.008)\end{array}$ & $\begin{array}{c}0.041 * * * \\
(0.011)\end{array}$ & $\begin{array}{l}-0.010 \\
(0.008)\end{array}$ \\
\hline Age3039 & $\begin{array}{c}-3.403 * * \\
(1.192)\end{array}$ & $\begin{array}{c}-3.085 * * \\
(1.057)\end{array}$ & $\begin{array}{l}-0.017 * \\
(0.009)\end{array}$ & $\begin{array}{l}-0.007 \\
(0.007)\end{array}$ & $\begin{array}{c}0.017 \\
(0.011)\end{array}$ \\
\hline Age4049 & $\begin{array}{c}-10.509 * * * \\
(1.761)\end{array}$ & $\begin{array}{c}-9.574 * * * \\
(1.327)\end{array}$ & $\begin{array}{c}-0.053 * * * \\
(0.010)\end{array}$ & $\begin{array}{c}-0.049 * * * \\
(0.010)\end{array}$ & $\begin{array}{c}0.069 * * * \\
(0.011)\end{array}$ \\
\hline Age 5059 & $\begin{array}{c}-12.416 * * * \\
(1.798)\end{array}$ & $\begin{array}{c}-11.756 * * * \\
(2.180)\end{array}$ & $\begin{array}{c}-0.070 * * * \\
(0.012)\end{array}$ & $\begin{array}{c}-0.060 * * * \\
(0.013)\end{array}$ & $\begin{array}{c}0.081 * * * \\
(0.018)\end{array}$ \\
\hline Age60m & $\begin{array}{c}-7.977 * * \\
(3.388)\end{array}$ & $\begin{array}{c}-9.565 * * \\
(4.097)\end{array}$ & $\begin{array}{c}-0.043 * * \\
(0.021)\end{array}$ & $\begin{array}{l}-0.043 * \\
(0.024)\end{array}$ & $\begin{array}{c}0.079 * * * \\
(0.024)\end{array}$ \\
\hline Secvocat & $\begin{array}{l}6.722 * * \\
(2.473)\end{array}$ & $\begin{array}{c}10.916^{* * * *} \\
(2.497)\end{array}$ & $\begin{array}{c}0.036 * * * \\
(0.011)\end{array}$ & $\begin{array}{c}0.065 * * * \\
(0.015)\end{array}$ & $\begin{array}{c}-0.078 * * * \\
(0.010)\end{array}$ \\
\hline Uni & $\begin{array}{c}21.154 * * * \\
(2.082)\end{array}$ & $\begin{array}{c}26.859 * * * \\
(2.534)\end{array}$ & $\begin{array}{c}0.125 * * * \\
(0.013)\end{array}$ & $\begin{array}{c}0.166^{* * * *} \\
(0.014)\end{array}$ & $\begin{array}{c}-0.127 * * * \\
(0.007)\end{array}$ \\
\hline Single & $\begin{array}{c}4.966 * * * \\
(1.643)\end{array}$ & $\begin{array}{c}3.847 * * \\
(1.469)\end{array}$ & $\begin{array}{c}0.028 * * * \\
(0.011)\end{array}$ & $\begin{array}{c}0.041 * * * \\
(0.011)\end{array}$ & $\begin{array}{l}-0.013 \\
(0.010)\end{array}$ \\
\hline Divwid & $\begin{array}{l}2.255^{*} \\
(1.217)\end{array}$ & $\begin{array}{c}1.856 \\
(1.728)\end{array}$ & $\begin{array}{c}0.002 \\
(0.004)\end{array}$ & $\begin{array}{c}0.010 \\
(0.010)\end{array}$ & $\begin{array}{c}0.008 \\
(0.009)\end{array}$ \\
\hline City1 & $\begin{array}{l}7.870 * * \\
(3.516)\end{array}$ & $\begin{array}{c}7.386 * \\
(4.096)\end{array}$ & $\begin{array}{c}0.039 * * \\
(0.019)\end{array}$ & $\begin{array}{c}0.031 \\
(0.027)\end{array}$ & $\begin{array}{c}-0.038 * * * \\
(0.015)\end{array}$ \\
\hline Bigt1 & $\begin{array}{c}-0.054 \\
(1.845)\end{array}$ & $\begin{array}{l}-1.446 \\
(2.540)\end{array}$ & $\begin{array}{c}0.002 \\
(0.011)\end{array}$ & $\begin{array}{l}-0.014 \\
(0.017)\end{array}$ & $\begin{array}{c}0.000 \\
(0.009)\end{array}$ \\
\hline Unemployed & $\begin{array}{c}-11.420 * * * \\
(2.435)\end{array}$ & $\begin{array}{c}-9.170 * * * \\
(2.053)\end{array}$ & $\begin{array}{c}-0.053 * * * \\
(0.012)\end{array}$ & $\begin{array}{c}-0.059 * * * \\
(0.013)\end{array}$ & $\begin{array}{c}0.043 * * * \\
(0.010)\end{array}$ \\
\hline Pens & $\begin{array}{l}-4.075^{*} \\
(2.261)\end{array}$ & $\begin{array}{l}-1.257 \\
(2.052)\end{array}$ & $\begin{array}{c}-0.026 * * \\
(0.013)\end{array}$ & $\begin{array}{l}-0.018 \\
(0.013)\end{array}$ & $\begin{array}{c}0.027 * * * \\
(0.010)\end{array}$ \\
\hline Hwstudent & $\begin{array}{c}5.125 * * * \\
(1.131)\end{array}$ & $\begin{array}{c}5.475 * * * \\
(1.454)\end{array}$ & $\begin{array}{c}0.030 * * * \\
(0.008)\end{array}$ & $\begin{array}{c}0.034 * * * \\
(0.010)\end{array}$ & $\begin{array}{c}-0.003 \\
(0.008)\end{array}$ \\
\hline Hhincq2 & $\begin{array}{c}3.616^{* *} \\
(1.411)\end{array}$ & $\begin{array}{c}4.732 * * \\
(1.590)\end{array}$ & $\begin{array}{c}0.020 * * * \\
(0.006)\end{array}$ & $\begin{array}{c}0.024 * * \\
(0.010)\end{array}$ & $\begin{array}{c}-0.026 * * \\
(0.011)\end{array}$ \\
\hline Hhincq3 & $\begin{array}{c}10.363 * * * \\
(1.769)\end{array}$ & $\begin{array}{c}12.247 * * * \\
(1.643)\end{array}$ & $\begin{array}{c}0.046 * * * \\
(0.008)\end{array}$ & $\begin{array}{c}0.067 * * * \\
(0.012)\end{array}$ & $\begin{array}{c}-0.060 * * * \\
(0.013)\end{array}$ \\
\hline Hhincq4 & $\begin{array}{c}23.994 * * * \\
(2.796)\end{array}$ & $\begin{array}{c}23.199 * * * \\
(2.603)\end{array}$ & $\begin{array}{c}0.118 * * * \\
(0.017)\end{array}$ & $\begin{array}{c}0.125 * * * \\
(0.016)\end{array}$ & $\begin{array}{c}-0.099 * * * \\
(0.015)\end{array}$ \\
\hline
\end{tabular}

Cont. 
Cont. Table 8

\begin{tabular}{|c|c|c|c|c|c|}
\hline $\mathrm{CZ}$ & $\begin{array}{c}36.912^{* * *} \\
(1.183)\end{array}$ & $\begin{array}{c}48.007 * * * \\
(1.839)\end{array}$ & $\begin{array}{c}0.258^{* * * *} \\
(0.006)\end{array}$ & $\begin{array}{c}0.269^{* * * *} \\
(0.008)\end{array}$ & $\begin{array}{c}-0.053^{* * * *} \\
(0.005)\end{array}$ \\
\hline SK & $\begin{array}{c}-21.011 * * * \\
(0.854)\end{array}$ & $\begin{array}{c}-4.491 * * * \\
(1.131)\end{array}$ & $\begin{array}{c}-0.064 * * * \\
(0.003)\end{array}$ & $\begin{array}{c}0.010 \\
(0.006)\end{array}$ & $\begin{array}{c}0.095^{* * *} \\
(0.005)\end{array}$ \\
\hline $\mathrm{HU}$ & $\begin{array}{c}-24.958 * * * \\
(1.113)\end{array}$ & $\begin{array}{c}-21.749 * * * \\
(1.263)\end{array}$ & $\begin{array}{c}-0.103 * * * \\
(0.004)\end{array}$ & $\begin{array}{c}-0.098 * * * \\
(0.007)\end{array}$ & $\begin{array}{c}0.032 * * * \\
(0.006)\end{array}$ \\
\hline PL & $\begin{array}{c}4.998 * * * \\
(1.078)\end{array}$ & $\begin{array}{c}12.827 * * * \\
(1.354)\end{array}$ & $\begin{array}{c}0.078 * * * \\
(0.006)\end{array}$ & $\begin{array}{c}0.085^{* * * *} \\
(0.008)\end{array}$ & $\begin{array}{c}0.035^{* * * *} \\
(0.006)\end{array}$ \\
\hline $\mathrm{EE}$ & $\begin{array}{l}-2.403 \\
(2.621)\end{array}$ & $\begin{array}{l}-2.133 \\
(2.314)\end{array}$ & $\begin{array}{c}0.033^{* *} \\
(0.015)\end{array}$ & $\begin{array}{c}0.008 \\
(0.014)\end{array}$ & $\begin{array}{c}-0.078^{* * * *} \\
(0.007)\end{array}$ \\
\hline LT & $\begin{array}{c}-48.400 * * * \\
(2.543)\end{array}$ & $\begin{array}{c}-21.990 * * * \\
(2.417)\end{array}$ & $\begin{array}{c}-0.159 * * * * \\
(0.008)\end{array}$ & $\begin{array}{c}-0.105 * * * \\
(0.013)\end{array}$ & $\begin{array}{c}-0.057 * * * * \\
(0.008)\end{array}$ \\
\hline LV & $\begin{array}{c}-36.907 * * * \\
(2.610)\end{array}$ & $\begin{array}{c}-22.350 * * * \\
(2.409)\end{array}$ & $\begin{array}{c}-0.131 * * * * \\
(0.009)\end{array}$ & $\begin{array}{c}-0.125^{* * * *} \\
(0.013)\end{array}$ & $\begin{array}{c}-0.096 * * * * \\
(0.006)\end{array}$ \\
\hline $\mathrm{BU}$ & $\begin{array}{c}-36.318 * * * \\
(0.649)\end{array}$ & $\begin{array}{l}-1.789 \\
(1.140)\end{array}$ & $\begin{array}{c}-0.101 * * * * \\
(0.004)\end{array}$ & $\begin{array}{c}-0.023 * * * \\
(0.007)\end{array}$ & $\begin{array}{c}0.120 * * * \\
(0.006)\end{array}$ \\
\hline RO & $\begin{array}{c}-10.190 * * * \\
(2.261)\end{array}$ & $\begin{array}{c}28.225 * * * \\
(2.064)\end{array}$ & $\begin{array}{c}-0.033 * * * \\
(0.011)\end{array}$ & $\begin{array}{c}0.142 * * * \\
(0.011)\end{array}$ & $\begin{array}{c}0.000 \\
(0.012)\end{array}$ \\
\hline $\mathrm{CR}$ & $\begin{array}{c}12.733 * * * \\
(2.476)\end{array}$ & $\begin{array}{c}18.710 * * * \\
(2.894)\end{array}$ & $\begin{array}{c}0.060 * * * \\
(0.015)\end{array}$ & $\begin{array}{c}0.067 * * * \\
(0.013)\end{array}$ & $\begin{array}{c}-0.056 * * * * \\
(0.009)\end{array}$ \\
\hline RU & $\begin{array}{c}-49.763 * * * \\
(2.184)\end{array}$ & $\begin{array}{c}-49.841^{* * *} \\
(1.553)\end{array}$ & $\begin{array}{c}-0.182 * * * \\
(0.008)\end{array}$ & $\begin{array}{c}-0.260 * * * \\
(0.008)\end{array}$ & $\begin{array}{c}0.256^{* * * *} \\
(0.012)\end{array}$ \\
\hline UA & $\begin{array}{c}-67.781 * * * \\
(1.330)\end{array}$ & $\begin{array}{c}-49.141^{* * *} \\
(1.815)\end{array}$ & $\begin{array}{c}-0.200 * * * \\
(0.003)\end{array}$ & $\begin{array}{c}-0.215 * * * \\
(0.008)\end{array}$ & $\begin{array}{c}0.235^{* * * *} \\
(0.006)\end{array}$ \\
\hline BY & $\begin{array}{c}-47.614 * * * \\
(1.659)\end{array}$ & $\begin{array}{c}-40.117 * * * \\
(1.871)\end{array}$ & $\begin{array}{c}-0.152 * * * \\
(0.004)\end{array}$ & $\begin{array}{c}-0.171 * * * \\
(0.011)\end{array}$ & $\begin{array}{c}0.244 * * * \\
(0.009)\end{array}$ \\
\hline YR91 & $\begin{array}{l}-7.585 \\
(9.395)\end{array}$ & $\begin{array}{c}16.783 \\
(12.188)\end{array}$ & $\begin{array}{c}-0.065^{*} \\
(0.037)\end{array}$ & $\begin{array}{c}0.096 \\
(0.060)\end{array}$ & \\
\hline YR92 & $\begin{array}{c}-22.513 * * * \\
(6.859)\end{array}$ & $\begin{array}{l}-2.674 \\
(9.048)\end{array}$ & $\begin{array}{c}-0.109 * * * \\
(0.025)\end{array}$ & $\begin{array}{l}-0.022 \\
(0.044)\end{array}$ & \\
\hline YR93 & $\begin{array}{c}-19.093^{* *} \\
(7.821)\end{array}$ & $\begin{array}{c}2.890 \\
(8.731)\end{array}$ & $\begin{array}{c}-0.095^{* * *} \\
(0.032)\end{array}$ & $\begin{array}{c}0.005 \\
(0.046)\end{array}$ & $\begin{array}{l}-0.038^{*} \\
(0.020)\end{array}$ \\
\hline YR95 & $\begin{array}{c}-24.157 * * \\
(10.586)\end{array}$ & $\begin{array}{c}-0.013 \\
(10.873)\end{array}$ & $\begin{array}{c}-0.092 * * \\
(0.040)\end{array}$ & $\begin{array}{l}-0.002 \\
(0.056)\end{array}$ & $\begin{array}{l}-0.009 \\
(0.035)\end{array}$ \\
\hline YR96 & $\begin{array}{c}-17.959 * \\
(9.210)\end{array}$ & $\begin{array}{c}1.145 \\
(7.822)\end{array}$ & $\begin{array}{c}-0.076^{*} \\
(0.039)\end{array}$ & $\begin{array}{l}-0.016 \\
(0.042)\end{array}$ & $\begin{array}{l}-0.016 \\
(0.019)\end{array}$ \\
\hline YR98 & $\begin{array}{c}-18.150 * \\
(10.088)\end{array}$ & $\begin{array}{c}-6.444 \\
(13.020)\end{array}$ & $\begin{array}{c}-0.084 * * * \\
(0.032)\end{array}$ & $\begin{array}{l}-0.042 \\
(0.060)\end{array}$ & $\begin{array}{c}0.025 \\
(0.034)\end{array}$ \\
\hline YR00 & $\begin{array}{c}-26.082 * * \\
(9.986)\end{array}$ & $\begin{array}{l}-8.820 \\
(7.309)\end{array}$ & $\begin{array}{c}-0.088^{* * *} \\
(0.037)\end{array}$ & $\begin{array}{l}-0.051 \\
(0.038)\end{array}$ & $\begin{array}{c}0.011 \\
(0.031)\end{array}$ \\
\hline YR01 & $\begin{array}{c}0.813 \\
(8.133)\end{array}$ & $\begin{array}{l}-0.764 \\
(7.643)\end{array}$ & $\begin{array}{c}0.014 \\
(0.037)\end{array}$ & $\begin{array}{l}-0.010 \\
(0.039)\end{array}$ & $\begin{array}{c}0.020 \\
(0.026)\end{array}$ \\
\hline Constant & $\begin{array}{l}-7.396 \\
(9.297)\end{array}$ & $\begin{array}{c}-2.619 \\
(10.120)\end{array}$ & & & \\
\hline $\begin{array}{l}\text { Observations } \\
\text { R-squared }\end{array}$ & $\begin{array}{c}72012 \\
0.18\end{array}$ & $\begin{array}{c}70532 \\
0.16\end{array}$ & 72012 & 70532 & 54553 \\
\hline
\end{tabular}

Notes: Standard errors clustered by country are reported in parentheses. * significant at 10 percent; ** significant at 5 percent; *** significant at 1 percent. Reference individual is male, age 20-29, cohort between 18 and 55 years old in 1990, less than secondary school education, married, living in rural or small town, employed, with household income in the 1st quartile. Reference country and year: Slovenia, 2004. 


\section{Data Appendix}

\section{a. Data acknowledgements and copyright}

This research was based on the data from the New Europe Barometer (waves I-VII), New Russia Barometer (waves I-XIII) and New Baltic Barometer (waves I-VI). These data have been produced by the Centre for the Study of Public Policy, University of Aberdeen / University of Strathclyde and by Richard Rose (U. of Aberdeen) and William Mishler (U. of Arizona). The data have been supplied by the UK Data Archive, under Crown copyright. The original data creators, depositors or copyright holders and the UK Data Archive bear no responsibility for our analysis or interpretation of these data.

The following data were obtained directly from the UK Data Archive:

Rose, R., New Europe Barometer I-V, 1991-1998 [computer file]. Colchester, Essex: UK Data Archive [distributor], October 2005. SN: 5241.

Rose, R., New Europe Barometer VI, 2001 [computer file]. Colchester, Essex: UK Data Archive [distributor], October 2005. SN: 5242.

Rose, R. and Mishler, W., New Europe Barometer VII, 2004-2005 [computer file]. Colchester, Essex: UK Data Archive [distributor], July 2007. SN: 5243.

Rose, R., New Russia Barometer, 2000-2001 [computer file]. Colchester, Essex: UK Data Archive [distributor], November 2003. SN: 4550.

Rose, R., New Russia Barometer XIII, 2004 [computer file]. Colchester, Essex: UK Data Archive [distributor], August 2007. SN: 5700.

\section{b. Tables and Figures}

Table A1: Sample size by country

\begin{tabular}{|c|c|c|c|c|c|c|c|c|c|c|}
\hline & 1991 & 1992 & 1993 & 1995 & 1996 & 1998 & 2000 & 2001 & 2004 & Total \\
\hline Bulgaria & 892 & 0 & 1035 & 1043 & 0 & 766 & 0 & 1086 & 1130 & 5952 \\
\hline Czech Republic & 611 & 1187 & 998 & 822 & 0 & 0 & 0 & 0 & 768 & 4386 \\
\hline Slovakia & 264 & 522 & 458 & 932 & 0 & 777 & 0 & 0 & 848 & 3801 \\
\hline Hungary & 756 & 594 & 818 & 876 & 0 & 0 & 0 & 650 & 474 & 4168 \\
\hline Poland & 941 & 962 & 763 & 819 & 0 & 0 & 0 & 629 & 590 & 4704 \\
\hline Romania & 949 & 956 & 0 & 0 & 0 & 1043 & 0 & 0 & 792 & 3740 \\
\hline Croatia & 0 & 982 & 989 & 0 & 0 & 0 & 0 & 0 & 0 & 1971 \\
\hline Belarus & 0 & 0 & 874 & 888 & 0 & 959 & 0 & 0 & 713 & 3434 \\
\hline Ukraine & 0 & 624 & 816 & 834 & 0 & 801 & 0 & 0 & 1578 & 4653 \\
\hline Russia & 0 & 1974 & 1741 & 1765 & 2310 & 1544 & 1686 & 1821 & 1820 & 14661 \\
\hline Estonia & 0 & 0 & 1474 & 1053 & 839 & 0 & 593 & 826 & 721 & 5506 \\
\hline Latvia & 0 & 0 & 1346 & 855 & 729 & 0 & 648 & 732 & 769 & 5079 \\
\hline Lithuania & 0 & 0 & 1688 & 766 & 855 & 0 & 960 & 1059 & 990 & 6318 \\
\hline Total & 5248 & 7801 & 13810 & 11284 & 4733 & 6500 & 3887 & 6803 & 11946 & 72012 \\
\hline
\end{tabular}

Source: Authors' tabulations form the New Barometer Surveys.

Notes: finals sample includes respondents with non-missing information on the key explanatory variables (as well as support for economic reforms). 
Table A2: Variables definitions and sources

\begin{tabular}{|c|c|}
\hline Variable & Description and sources \\
\hline \multicolumn{2}{|l|}{ Dependent variables: } \\
\hline Distec / Distpol & $\begin{array}{l}\text { Distance between present and past evaluations of the economic / political system. } \\
\text { Constructed as the difference between individual rankings of the functioning of the } \\
\text { present economic / political system, and the past socialist economy / political } \\
\text { system. Ranges from }-200 \text { and }+200 \text { and is treated as continuous. }\end{array}$ \\
\hline \multirow{2}{*}{$\begin{array}{l}\text { Positive, Negative, Nostalgic, } \\
\text { Pro-Market / } \\
\text { Compliant, Skeptic, } \\
\text { Reactionary, Democrat }\end{array}$} & $\begin{array}{l}\text { Two groups of binary mutually exclusive variables defining whether individual } \\
\text { belongs to a specific group based on his evaluations of past and present economic / } \\
\text { political systems. }\end{array}$ \\
\hline & Source: New Europe Barometers, New Russian Barometers, New Baltic Barometers. \\
\hline \multicolumn{2}{|l|}{$\begin{array}{l}\text { Independent individual } \\
\text { characteristics: }\end{array}$} \\
\hline Female & Dummy equals to 1 if individual is female \\
\hline Age $<30$ & Dummy equals 1 if individual's age is less than 30 years old (Reference category) \\
\hline Age 30-39 & Dummy equals 1 if individual's age is greater than 30 and less than 39 years old \\
\hline Age 40-49 & Dummy equals 1 if individual's age is greater than 40 and less than 49 years old \\
\hline Age 50-59 & Dummy equals 1 if individual's age is greater than 50 and less than 59 years old \\
\hline Age $>60$ & Dummy equals 1 if age is greater than 60 years old \\
\hline Elementary education & Dummy equals 1 if individual has elementary education (Reference category) \\
\hline $\begin{array}{l}\text { Secondary or vocational } \\
\text { education }\end{array}$ & Dummy equals 1 if individual has secondary or vocational education \\
\hline University & Dummy equals 1 if individual has university degree \\
\hline Married & Dummy equals 1 if individual is married or cohabiting (Reference category) \\
\hline Single & Dummy equals 1 if individual is single \\
\hline Divorced or widowed & Dummy equals 1 if individual is divorced separated or widowed \\
\hline Small town or rural & $\begin{array}{l}\text { Dummy equals } 1 \text { if individual resides in a small town or rural area (with population } \\
\text { less or equal to 5000; in Russia <20000) (Reference category) }\end{array}$ \\
\hline Big town & $\begin{array}{l}\text { Dummy equals } 1 \text { if individual resides in a big town (with population greater than } \\
5000 \text { and less than } 100000 \text {; in Russia - between } 20000 \text { and } 1000000 \text { ) }\end{array}$ \\
\hline City & $\begin{array}{l}\text { Dummy equals } 1 \text { if individual resides in a city including capital (with population } \\
>100000 \text {; in Russia }>1000000 \text { ) }\end{array}$ \\
\hline Employed & $\begin{array}{l}\text { Dummy equals } 1 \text { if individual is employed (full-time part-time family helper } \\
\text { apprentice or self-employed including and working pensioners in some countries) }\end{array}$ \\
\hline Unemployed & $\begin{array}{l}\text { Dummy equals } 1 \text { if individual is unemployed (including both with and without benefits } \\
\text { in Russia) }\end{array}$ \\
\hline Pensioner & Dummy equals 1 if individual is a pensioner \\
\hline Student or housewife & $\begin{array}{l}\text { Dummy equals } 1 \text { if individual is a house-keeper or a student since in several } \\
\text { countries it was not possible to disentangle these two categories. }\end{array}$ \\
\hline 1st hh. income quartile & $\begin{array}{l}\text { Dummy equals } 1 \text { if household is in the first quartile of the country-specific income } \\
\text { distribution (Reference category) }\end{array}$ \\
\hline $2^{\text {nd }} \mathrm{hh}$. income quartile & $\begin{array}{l}\text { Dummy equals } 1 \text { if household is in the second quartile of the country-specific income } \\
\text { distribution }\end{array}$ \\
\hline
\end{tabular}




\begin{tabular}{|c|c|}
\hline $3^{\text {rd }}$ hh. income quartile & $\begin{array}{l}\text { Dummy equals } 1 \text { if household is in the third quartile of the country-specific income } \\
\text { distribution }\end{array}$ \\
\hline $4^{\text {th }}$ hh. income quartile & $\begin{array}{l}\text { Dummy equals } 1 \text { if household is in the fourth quartile of the country-specific income } \\
\text { distribution }\end{array}$ \\
\hline Minority & $\begin{array}{l}\text { Dummy equals } 1 \text { if individual belongs to an ethnic minority in a country (in the Baltic } \\
\text { States) }\end{array}$ \\
\hline $\begin{array}{l}\text { Number of weeks with } \\
\text { hardship }\end{array}$ & $\begin{array}{l}\text { Number of weeks during which a person was either unemployed or salary was } \\
\text { delayed or not paid in full last year }(1993,1995,1996,1998)\end{array}$ \\
\hline Doing without & $\begin{array}{l}\text { Destitution scale, to indicate the degree of hardship experienced (increasing from } 0 \\
\text { to } 9) \text { based on information whether a person or his family had to live without food, } \\
\text { heating, electricity or clothes }(1993-2001)\end{array}$ \\
\hline Reforms right & $\begin{array}{l}\text { Dummy equals } 1 \text { if individual thinks that reforms in his country are being conducted } \\
\text { at the right speed (Reference category) }(1995,1996)\end{array}$ \\
\hline Reforms fast & $\begin{array}{l}\text { Dummy equals } 1 \text { if individual thinks that reforms in his country are going too fast } \\
(1995,1996)\end{array}$ \\
\hline Reforms slow & $\begin{array}{l}\text { Dummy equals } 1 \text { if individual thinks that reforms in his country are going too slow } \\
(1995,1996)\end{array}$ \\
\hline Parliament suspend & $\begin{array}{l}\text { Dummy equals } 1 \text { if individual would approve if the Parliament was suspended (1991 - } \\
\text { 2004) }\end{array}$ \\
\hline Leader & $\begin{array}{l}\text { Dummy equals } 1 \text { if individual agrees with the statement: it would be better to get rid } \\
\text { of Parliament and elections and have a strong leader (1992-2004) }\end{array}$ \\
\hline Corruption & $\begin{array}{l}\text { Dummy equals } 1 \text { if individual thinks that most or almost all "public officials are } \\
\text { engaged in bribe-taking and corruption" in his country and equals zero if he thinks } \\
\text { that "very few" or "less than half public officials are corrupt" }(2001,2004) \text {. }\end{array}$ \\
\hline Equal income & $\begin{array}{l}\text { Dummy that equals } 1 \text { if individual agrees with the statement that "incomes should be } \\
\text { made more equal so there is no big difference in income" as opposed to the } \\
\text { statement "Individual achievement should determine how much people are paid" } \\
(1992,1993,1995,1998,2004)\end{array}$ \\
\hline Return to Communism & $\begin{array}{l}\text { Dummy equals } 1 \text { if individual agrees with the statement "We should return to } \\
\text { Communist rule" (1993-2004) }\end{array}$ \\
\hline Ex-Communist & $\begin{array}{l}\text { Dummy equals } 1 \text { if individual or his family were members of the Communist party } \\
(1993,1995,1998)\end{array}$ \\
\hline Trust parties & $\begin{array}{l}\text { Variable indicating the degree of individual's trust in political parties (ranges from } 1 \\
\text { to } 7)(1992-2004)\end{array}$ \\
\hline Trust Parliament & $\begin{array}{l}\text { Variable indicating the degree of individual's trust in Parliament (ranges from } 1 \text { to } 7 \text { ) } \\
(1992-2004)\end{array}$ \\
\hline Trust President & $\begin{array}{l}\text { Variable indicating the degree of individual's trust in President (ranges from } 1 \text { to } 7 \text { ) } \\
(1993-2004)\end{array}$ \\
\hline \multirow[t]{2}{*}{ Trust people } & $\begin{array}{l}\text { Variable indicating the degree of individual's trust in people of his country (ranges } \\
\text { from } 1 \text { to } 7)(1998-2004)\end{array}$ \\
\hline & Source: New Europe Barometers, New Russian Barometers, New Baltic Barometers. \\
\hline \multicolumn{2}{|c|}{ Macroeconomic variables and } \\
\hline Unemployment rate & $\begin{array}{l}\text { Unemployment rate (Source: EBRD. For Belarus the data are from IMF International } \\
\text { Financial Statistics CD Rom for Ukraine - from World Development Indicators CD } \\
\text { Rom for Estonia in } 1990 \text { and } 1991 \text { - from the World Development Indicators online } \\
\text { database) }\end{array}$ \\
\hline GDP per capita & $\begin{array}{l}\text { GDP per capita PPP (constant } 2000 \text { international \$) (Source: World Development } \\
\text { Indicators online database) }\end{array}$ \\
\hline
\end{tabular}


Inflation

EBRD Transition Indicators

Hospital beds

Gini Index

Democracy

Governance
Inflation GDP deflator (annual percent) (Source: World Development Indicators online database)

Average of EBRD indicators of the progress in transition lagged one year (Source: EBRD 2007)

Hospital beds per 1000 of people in a country (Source: World Development Indicators CD Rom)

Gini index (Source: Transmonee dataset, http://www.transmonee.org/). For Bulgaria Czech Republic Estonia Latvia Lithuania Ukraine Croatia and Belarus 1990 is used instead of 1991. In Latvia 1997 is used instead of 1995 and 2000 instead of 2001. For Lithuania 1996 is used instead of 1995. For Russia instead of 1993 use 1994. For Slovakia instead of 1995 use 1996. For Slovenia and Ukraine instead of 2004 use 2002

Democracy Indicator, based on an additive eleven-point scale (0-10) (Source: Polity IV)

Average of the World Bank Governance Indicators

(Source: http://info.worldbank.org/governance/wgi/sc chart.asp ).

Based on the following six indicators: Voice and Accountability / Political Stability / Government Effectiveness / Regulatory Quality / Rule of Law / Control of Corruption. Note: data from 1996 is used instead of 1995, and from 2002 instead of 2001 


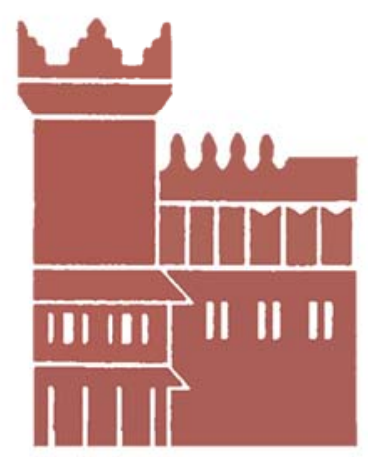

Alma Mater Studiorum - Università di Bologna DEPARTMENT OF ECONOMICS

Strada Maggiore 45

40125 Bologna - Italy

Tel. +39051 2092604

Fax +390512092664

http://www.dse.unibo.it 